\title{
Immunochemistry of the Outer Retina
}

\author{
ASAAD SHALLAL*, NICOL M. McKECHNIE** AND SAHAR AL-MAHDAWI*
}

London

\begin{abstract}
Summary
The immunochemistry of the outer retina is discussed with particular reference to photoreceptor cells, the retinal pigment epithelium and the interphotoreceptor space. The antigens identified and the techniques utilised are summarised.
\end{abstract}

The retinal pigment epithelium (RPE) and the photoreceptor cells form a functionally interdependent unit which is responsible for the initial photochemical events in the processes giving rise to vision. As might be expected such specialised cells have a variety of unique proteins to support their specialised functions in addition to elements common to many cell types.

This paper will be concerned with the immunochemistry of the developed outer retina which, for our purposes, shall be defined as the photoreceptor cells, the subretinal or interphotoreceptor space (Fig 1), and the RPE. Müller cells and other elements of the inner retina will not be discussed.

Immunochemistry can be applied to the study of the outer retina in two main areas. Firstly, the identification and localisation of known proteins using antisera or monoclonal antibodies (MAbs). Examples might include the identification of cytoskeletal elements such as actin and tubulin in RPE cells or the localisation of rhodopsin and S-antigen in photoreceptor cells. The second, and possibly more exciting area, is the use of MAbs as dissection tools in the indentification and characterisation of previously unknown proteins. This approach has been elegantly demonstrated by Molday and coworkers $^{1}$ in the identification of peripherin, a protein of the rod outer segment.

The two complementary techniques of immunoblotting $^{2}$ (sometimes referred to as
Western blotting) and immunocytochemistry are particularly useful in the indentification, characterisation and localisation of antigens.

\section{Immunoblotting}

Recent advances in biochemical techniques made possible the transfer of a resolved mixture of proteins and other molecules from gels (acrylamide or agarose) onto an immobilising matrix. Nitrocellulose membrane has been the most widely used matrix. ${ }^{2}$ This technique has attracted a wide range of applications in basic, clinical and immunologial research. In the latter, antibodies (monoclonal or polyclonal) can react with the antigens bound onto the nitrocellulose membrane (immunoblotting). The reacted antibodies can then be easily identified by autoradiography if they are conjugated to a radioactive ligand $\left({ }^{125} \mathrm{I}\right)$ or by the addition of a suitable chromogenic substrate, if the ligand is an enzyme (like peroxidase or alkaline phosphtase). Alternatively, if the first antibody is not linked to a ligand a second antibody (anti-immunoglobulin) conjugated to an appropriate probe (radioactive ligand or an enzyme) could be used in the same manner to visualise antibody antigen reaction onto the nitrocellulose membrane.

Immunoblotting is useful in analysing the immune response in certain retinal diseases, especially those associated with autoimmunity. ${ }^{3}$ Its application has also proved invaluable in identifying antigens normally masked by other predominant proteins which co-migrate with

From Institute of Ophthalmology, Department of Pathology, Judd Street, ${ }^{*}$ and Cayton Street, ${ }^{* *}$ London.

Correspondence to: Dr N M McKechnie, Department of Pathology, Institute of Ophthalmology, 17/25 Cayton Street, London ECIV 9AT. 
them on an SDS-polyacrylamide gel. ${ }^{1}$ It is becoming evident that immunoblotting is one of the most accurate methods of defining the specificity of an antibody and as a means of identifying common epitopes on related or unrelated molecules (Fig 2).

\section{Immunocytochemistry}

As with most microscopical techniques vastly different degrees of resolution are obtainable. At one end of the range, immunofluorescence Staining of frozen sections can be useful (Fig 3), While at the other end of the spectrum lies Wectron microscopy (EM) immunocytochemiiry using pre- and post- embedding techniques hnd a variety of electron dense markers of which colloidal gold is becoming the most popular due 10. its small size and extreme electron density. ${ }^{4}$

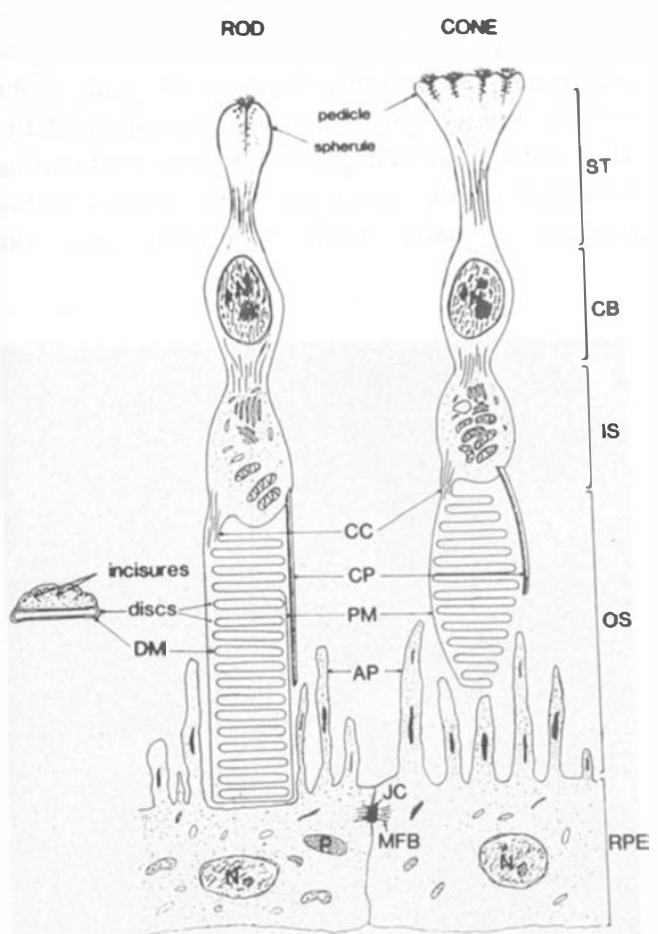

\footnotetext{
Fig. 1. Diagrammatic representation of the outer retina showing a rod, cone and the retinal pigment epithelium. AP: apical processes CB: cell body, CC: connecting cilium, CP: calycal processes, DM: disc membrane, IS: inner segment, JC: junctional complex, MFB: microfilament bundle, $N$ : nucleus, OS: outer segment, P: phagosome, PM: plasma membrane, $R P E$, retina pigment epithelium, ST: synaptic cerminal.
}

Immunofluorescence or immunoperoxidase staining of frozen sections of lightly fixed materials using methanol and acetone has the

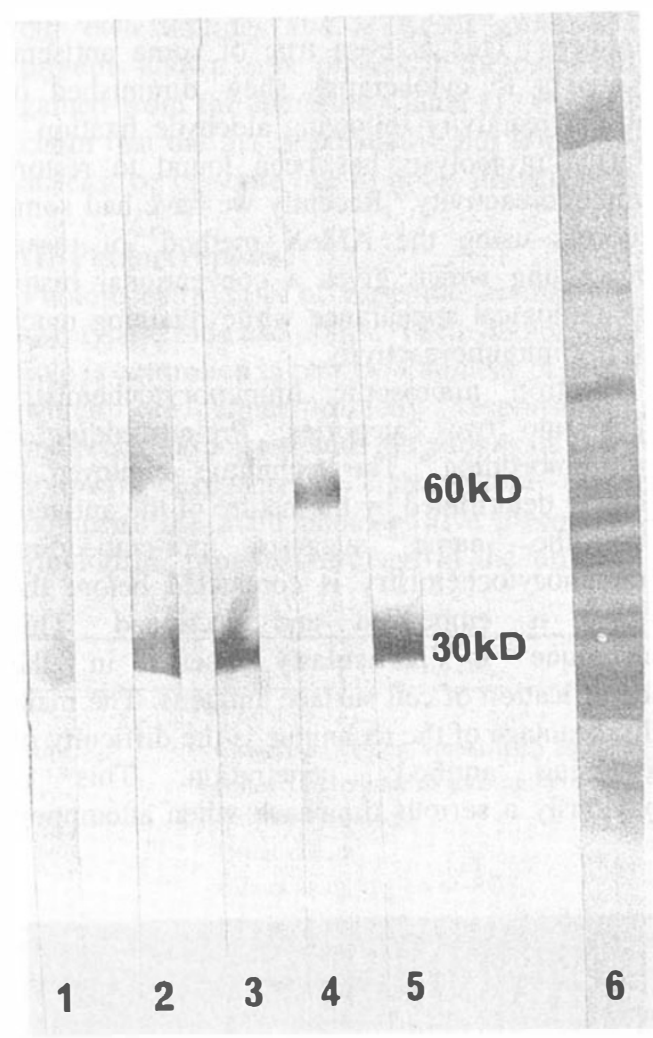

Fig. 2. Example of an immunoblotting experiment. Lanes 1-5 are blots following gel electrophoresis of purified rod outer segments. Lane 6 is a blot following the electrophoresis of retinal extract. Lanes 1 and 6 have been stained with amido black to show the protein bands present. In lane 1 faint staining of $a$ band corresponding to opsin can be seen. In lane 6 numerous protein bands are present. Lane 2, Blotted Ros proteins immunostained using MAb ROS $4 C 4$. This antibody probably recognises opsin. Faint bands corresponding to the dimer and trimer of opsin are also visible. Lane 3, Blotted ROS proteins immunostained using MAb ROS 4A2. Strong staining of $a$ band at approximately $32 k D$ is visible. EM immunocytochemistry suggests that this $M A b$ recognises peripherin (see Fig. 4). Lane 4, Blotted ROS proteins immunostained using MAb ROS IF2. Strong staining of a band at approximately $60 \mathrm{kD}$ is present. This protein has not been identified as yet. Lane 5. Transferred ROS proteins immunostained using MAb ROS 1F4. Strong staining of a band at approximately $32 k D$ is present. This $M A b$ probably recognises opsin. 
advantage of minimal loss of immunoreactivity. Frequently MAbs will only work on such material. Following conventional fixation with aldehydes, many MAbs fail to react with their antigens. This is even true of some antisera. Antisera to cytokeratins show diminished or absent reactivity following aldehyde fixation. ${ }^{5}$ Partial proteolysis has been found to restore immunoreactivity. ${ }^{6}$ Recently we have had some success using the AMeX method ${ }^{7}$ of tissue processing which gives a conventional histophathological appearance while retaining much of the immunoreactivity.

Electron microsopic immunocytochemistry falls into two categories: Pre-embedding ${ }^{8}$ or post-embedding. ${ }^{9}$ The technique employed is largely determined by the nature of the antigen. As the name suggests pre-embedding immunocytochemistry is conducted before the tissue is embedded and sectioned. This technique is particularly useful in the identification of cell surface antigens. The main disadvantage of the technique is the difficulty of assessing antibody penetration. This is obviously a serious drawback when attempting

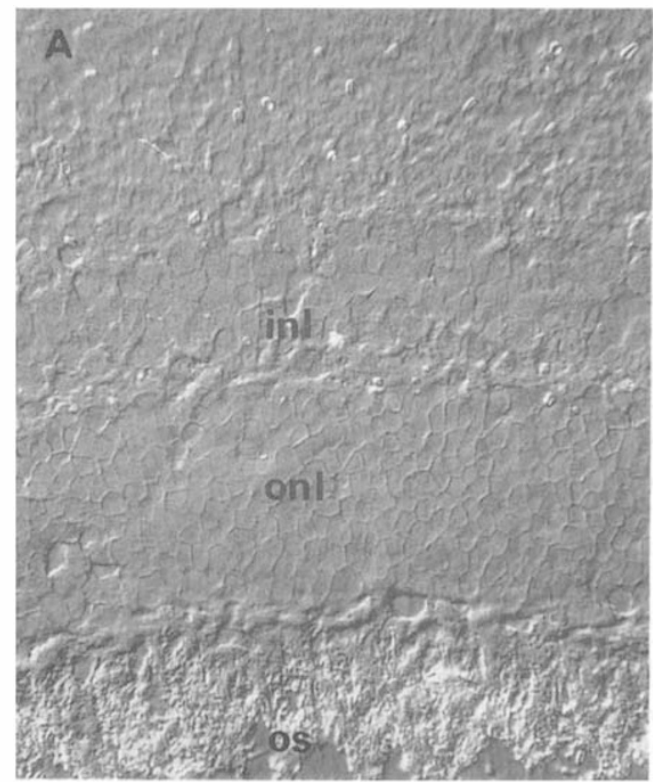

Fig. 3. (A) Differential interference contrast micrograph of a cryostat section of bovine retina. The outer segments (os), outer nuclear layer (onl), and the inner nuclear layer (inl) are particularly prominant. to dentify intracellular antigens. Cells can be made permeable to antibodies using detergents such as Triton $\mathrm{X}-100$ but this inevitably results in poorer morpholgical preservation. Postembedding immunocytochemistry attempts to preserve tissue immunoreactivity through all the steps of processing prior to sectioning. The demands of the technique have resulted in the production of specialised resins such as Lowicryl K4M and LR gold which can be polymerised at low temperatures. Following sectioning the antibody solution is incubated with the EM sections on nickel or gold grids. Most commonly, antibody binding is detected using colloidal gold conjugated to immunoglobulins or protein A. ${ }^{4}$ For example colloidal gold conjugated with an anti-mouse immunoglobulin would be used to detect the binding of a MAb raised in mouse to the tissue section. It should be noted that in gold conjugates, the binding between the gold probe and the immunoglobulin is purely electrostatic. The main disadvantage of the post embedding technique is the need for some sort of initial fixation (usually mild aldehyde) and the

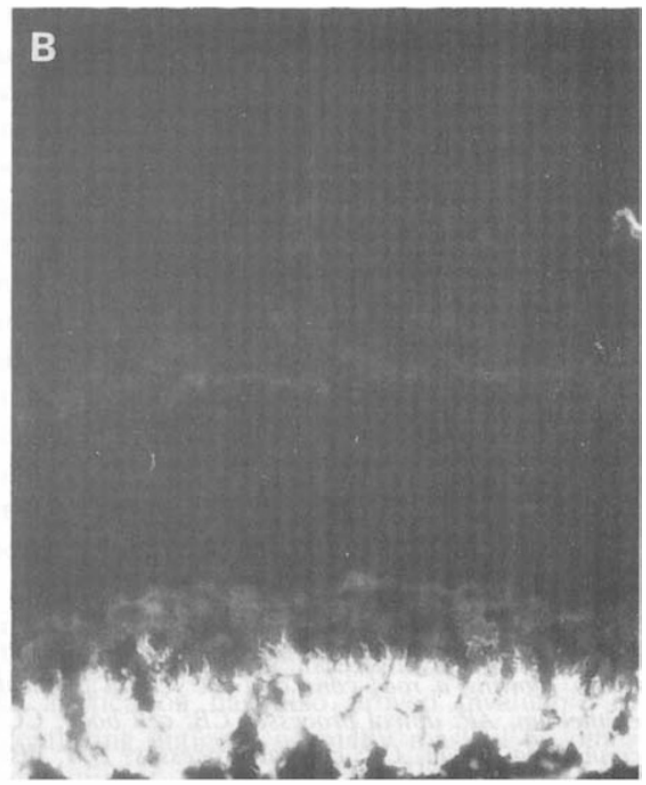

(B) The same section viewed using epi-fluorescence to demonstrate the intense staining of the outer segments produced using a monoclonal (ROS IF2) specific for $a-60 k D$ protein of the outer segment. Both $x 250$. 
subsequent loss of immunoreactivity. Ultrastructural preservation, although often surprisingly good, is not as good as can be achieved by conventional EM techniques.

\section{Applications}

Many groups are now producing MAbs to retinal cells as probes of structure, function and development. We are pincipally interested in the interaction between RPE cells and photoreceptors (e.g. phagocytosis) and the identification of RPE cells in cultured and pathological material. In the course of these investigations we have been producing MAbs to photoreceptor and RPE cell antigens. Once such antibodies have been characterised to the degree of knowing molecular weight of the antigen (immunoblotting) and its tissue location (immunocytochemistry) it is of importance to compare these findings with descriptions of known photoreceptor, interphotoreceptor matrix and RPE antigens. This paper presents some of our own findings and a list of some of the proteins known to be present in the outer retina gained from the literature (Table I). We do not claim that the list is exhaustive but hope it will at least be of some use to other investigators.

\section{(I) Photoreceptors}

Photoreceptor cells of vertebrate retinas are of two types, rods and cones. Their photosensitive role is controlled in part by a number of proteins which are either directly responsible or indirectly associated with the photolysis cascade following exposure to light. These proteins comprise the main photosenstive glycoprotein, rhodopsin, proteins involved in the process of

\begin{tabular}{|c|c|c|c|c|c|}
\hline$A g$ & $A b$ & $\operatorname{Ref}$ & Spp & Tech & Localisation \\
\hline \multicolumn{6}{|l|}{ Photoreceptor } \\
\hline actin & AS & 57 & frog & ferritin & $\begin{array}{l}\text { Calycal processes, apical RPE and } \\
\text { connecting cilium of rods and cones. }\end{array}$ \\
\hline actin & AS & 58 & $\begin{array}{l}\text { rat cow monkey } \\
\text { man }\end{array}$ & ferritin/EM & $\begin{array}{l}\text { Calycal Processes. } \\
\text { Distal cilium. }\end{array}$ \\
\hline $\begin{array}{l}\text { calmodulin } \\
\text { calmodulin }\end{array}$ & AS & 59 & frog & IF & Ciliary body region of ROS. \\
\hline binding protein & AS & 59 & frog cow & IB & \\
\hline CNP ase & AS & 65 & cow & PAP & ROS, elipsoid of RIS. \\
\hline CNP ase & AS & 66 & chick & PAP & $\begin{array}{l}\text { Photoreceptor plasma membrane. } \\
\text { OS and IS of rods and cones. }\end{array}$ \\
\hline $\begin{array}{l}\text { cone related } \\
\text { antigen }(1) \\
\text { cone related }\end{array}$ & $\begin{array}{l}\text { MAb COS-1 } \\
\text { anti } 33 \mathrm{kD} \\
\text { MAb }\end{array}$ & 62 & chick & IB EM & $\begin{array}{l}\text { Outer segment of double cones. } \\
\text { and some single cones. }\end{array}$ \\
\hline antigen (2) & $50-1 \mathrm{~B} 11$ & 63 & $\begin{array}{l}\text { various vertebrates } \\
\text { monkey man }\end{array}$ & IF IP & Lamellae of COS. \\
\hline $\begin{array}{l}\text { cone related } \\
\text { antigen }(3)\end{array}$ & $\begin{array}{l}\text { MAb CSA-1 } \\
\text { anti-54kd }\end{array}$ & 64 & pig & IB IF & $\begin{array}{l}\text { COS/CIS cell bodies, axons, } \\
\text { Synaptic pedicles. }\end{array}$ \\
\hline CSAD & AS $\alpha$-subunit & 71 & rat & IP EM & Rod and cones (especially spherules). \\
\hline G-protein & AS $\alpha$-subunit & 47 & cow chick & IB & \\
\hline complex & & & $\begin{array}{l}\text { cow chick monkey } \\
\text { man }\end{array}$ & IF & Rod photoreceptors. \\
\hline $\begin{array}{l}\text { G-protein } \\
\text { complex }\end{array}$ & MAb $\alpha$-subunit & 48 & frog & IF & ROS. \\
\hline $\begin{array}{l}\text { HIOMT } \\
\text { LIMP (ROS }\end{array}$ & AS & 67 & rat cow man & PAP IB & Outer segments, inner nuclear layer. \\
\hline $\begin{array}{l}\text { 1.2) } \\
\text { LIMP (ROS }\end{array}$ & AS & 51 & frog & ferritin/EM & Incisures of ROS discs. \\
\hline 1.2) & AS & 52 & frog & ferritin/EM & $\begin{array}{l}\text { Margins of red and green ROS. } \\
\text { Discs and margins of COS lamellae. }\end{array}$ \\
\hline $\begin{array}{l}\text { LIMP (ROS } \\
1.2)\end{array}$ & $\begin{array}{l}\text { MAb 3D12 } \\
\text { 4B2 } \\
\text { anti-(ROS 1.2) }\end{array}$ & 53 & cow & ferritin/EM & $\begin{array}{l}\text { Margins of ROS discs and its } \\
\text { exposure on the cytoplasmic surface. }\end{array}$ \\
\hline
\end{tabular}


Table 1 continued

\begin{tabular}{|c|c|c|c|c|c|}
\hline$A g$ & $A b$ & $\operatorname{Ref}$ & Spp & Tech & Localisation \\
\hline PDE & AS & 39 & fish frog rat & immunoprecipitation & \\
\hline \multirow[t]{3}{*}{ PDE } & MAb ROS 1 & 40 & cow man & IB. IF & ROS. COS. \\
\hline & ROS 1 & 40 & $\begin{array}{l}\text { fish frog rat } \\
\text { man }\end{array}$ & $\begin{array}{l}\text { immunoadsorption } \\
\text { IB }\end{array}$ & \\
\hline & ROS 2 & 40 & cow & & \\
\hline PDE & MAb & 41 & cow & IB & \\
\hline PDE & AS & 42,43 & cow & $\mathrm{EM}$ & ROS, lumen of connecting cilium. RIS. \\
\hline peripherin & Mabs 2B6 3B6 & 1 & cow & gold/EM & Rim of discs. \\
\hline rhodopsin & AS & 13 & frog & IF & Rod outer segment. \\
\hline rhodopsin & AS & 14 & cow mouse & IP/EM & $\begin{array}{l}\text { Disc and plasma membrane of ROS, } \\
\text { small quantity in the connecting } \\
\text { cilium and plasma membrane of the } \\
\text { inner segment. }\end{array}$ \\
\hline rhodopsin & AS & 15 & frog & ferritin/EM & $\begin{array}{l}\text { Disc and plasma membrane of ROS, } \\
\text { RIS, little labelling in the } \\
\text { connecting cilium. }\end{array}$ \\
\hline rhodopsin & MAb RET-P1 & $16,17 r$ & rat & $\begin{array}{l}\text { IF.PAP/EM } \\
\text { ferritin/EM }\end{array}$ & $\begin{array}{l}\text { Entire rod photoreceptors except } \\
\text { synaptic ending and outer plexiform } \\
\text { layer. }\end{array}$ \\
\hline \multirow[t]{15}{*}{ rhodopsin } & $\mathrm{MAb} 4 \mathrm{D} 2$ & 18 & cow & gold/EM & External surface of rod outer segment. \\
\hline & $4 \mathrm{~A} 2$ & 18 & cow & gold/EM & External surface of rod outer segment. \\
\hline & $5 \mathrm{~A} 3$ & 18 & cow & gold/EM & External surface of rod outer segment. \\
\hline & $4 \mathrm{~A} 3$ & 18 & cow & gold/EM & External surface of rod outer segment. \\
\hline & 4D2 & 18 & frog & gold/EM & Red rod outer segments. \\
\hline & $4 \mathrm{~A} 2$ & 18 & frog & gold/EM & Light labelling green ROS, COS. \& RIS. \\
\hline & $5 \mathrm{~A} 3$ & 18 & frog & gold/EM & Light labelling green ROS, COS. \& RIS. \\
\hline & $4 \mathrm{~A} 3$ & 18 & frog & gold/EM & Light labelling green ROS, COS. \& RIS. \\
\hline & 1D4 & 18 & cow & gold/EM & ROS slightly. RIS \& connecting cilium. \\
\hline & $1 \mathrm{D} 4$ & 18 & frog & gold/EM & Red and green ROS. \\
\hline & $2 \mathrm{Cl}$ & 18 & cow & gold/EM & ROS. \\
\hline & $2 \mathrm{Cl}$ & 18 & frog & gold/EM & Red and green ROS. \\
\hline & 3D6 & 18 & cow frog & gold/EM & ROS and COS. \\
\hline & $1 \mathrm{C5}$ & 18 & cow & gold/EM & ROS. \\
\hline & $3 \mathrm{~A} 6$ & 18 & cow & gold/EM & ROS. \\
\hline S-antigen & AS & $\begin{array}{l}19,25, \\
29\end{array}$ & g.pig & IF & Photoreceptor cells and pineal gland. \\
\hline S-antigen & AS & 54 & g.pig rabbit & IF & Photoreceptor cells and pineal gland. \\
\hline S-antigen & AS & 28 & rabbit & IF & Outer segments. \\
\hline S-antigen & AS & 30 & rat & IF gold/EM & Rod outer segments. \\
\hline S-antigen & AS & 31 & rat & PAP/EM & Outer segments and around cell bodies. \\
\hline S-antigen & AS & 29 & $\begin{array}{l}\text { rabbit light and } \\
\text { dark adapted }\end{array}$ & IP/EM & $\begin{array}{l}\text { Photoreceptor discs, plasma membrane, } \\
\text { microvilli. }\end{array}$ \\
\hline S-antigen & AS & 32 & $\operatorname{man}$ & Gold/EM & Proximal portion of ROS. cones negative. \\
\hline S-antigen & $\begin{array}{l}\text { MAbs S6H8 } \\
\text { S8D8,S2D2 } \\
\text { S7D6,S8D1 } \\
\text { S9E2 }\end{array}$ & 34,36 & $\begin{array}{l}\text { various } \\
\text { vertebrate and } \\
\text { invertebrates }\end{array}$ & IF & Photoreceptor cells. \\
\hline S-antigen & $\begin{array}{l}\text { MAbs RSA1/ } \\
83 \text { RSA2/83 }\end{array}$ & 33 & cow & $\begin{array}{l}\text { radio immuno- } \\
\text { cytochemical }\end{array}$ & $\begin{array}{l}\text { A1 distal protein of ROS. } \\
\text { A2 ROS and RIS. }\end{array}$ \\
\hline S-antigen & $\begin{array}{r}\text { MAbs: A9C6 } \\
\text { A1C5 }\end{array}$ & 35 & $\begin{array}{l}\text { vertebrates } \\
\text { including human } \\
\text { and dev. rat }\end{array}$ & IF. IP & $\begin{array}{l}\text { Photoreceptor cell layer in all species } \\
\text { tested. } \\
\text { In neuroblastic cell layer }-3 \text { day rat. } \\
\text { Entire photoreceptor cell }-7 \text { day rat } \\
\text { and all other species. }\end{array}$ \\
\hline
\end{tabular}


Table 1 continued

\begin{tabular}{|c|c|c|c|c|c|}
\hline$A g$ & $A b$ & $\operatorname{Ref}$ & Spp & Tech & Localisation \\
\hline S-antigen & $\begin{array}{l}\text { MAb(rat) } \\
\text { S2.4.C5 }\end{array}$ & 37 & Pig human & gold/EM & Photoreceptor cell. \\
\hline spectrin & $\mathrm{MAb} 4 \mathrm{~B} 2$ & 61 & cow & IB gold/EM & Rims of ROS discs. \\
\hline tubulin & AS & 59 & frog & IF & Cilium,ciliary microtubules in ROS. \\
\hline tubulin & MAb & 60 & frog & IF & Ciliary microtubules in ROS. \\
\hline visinin & AS & 69 & crab, frog, cat, man & IF & Cone cells. \\
\hline $\begin{array}{l}\text { calbindin } \\
\text { (visinin) }\end{array}$ & AS & 70 & pigeon chick & PAP & Mainly cone cells. \\
\hline \multicolumn{6}{|c|}{ Interphotoreceptor Space } \\
\hline C-6-S & $\begin{array}{l}\text { MAb anti } \\
\text { C-6-S }\end{array}$ & 89 & monkey & IF & Cone sheath. \\
\hline IRBP & AS & 76 & $\begin{array}{l}\text { rat cow monkey } \\
\text { man }\end{array}$ & IF. PAP. EM & $\begin{array}{l}\text { IPS RPE apical surface. Plasma } \\
\text { membrane of CIS and RIS. }\end{array}$ \\
\hline IRBP & AS & 90 & $\begin{array}{l}\text { rabbit rat cow } \\
\text { man }\end{array}$ & gold/EM & As above. \\
\hline IRBP & AS & 82 & $\operatorname{man}$ & IF. IP & $\begin{array}{l}\text { Space bounded by RPE apical surface } \\
\text { and the external limiting membrane. }\end{array}$ \\
\hline IRBP & AS & 83 & rat & IF & As above. \\
\hline IRBP & AS & 84 & 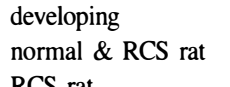 & IF-PAP & $\begin{array}{l}\text { P2-P8 space between neuroblastic layer } \\
\text { and RPE. P10 = IPS. }\end{array}$ \\
\hline IRBP & AS & 80 & $\begin{array}{l}\text { RCS rat } \\
\text { man }\end{array}$ & $\begin{array}{l}\text { IF-PAP } \\
\text { IF }\end{array}$ & $\begin{array}{l}\text { Staining decreases Pl8-P45. } \\
\text { Extended fluorescence from the apical } \\
\text { border of the RPE to the external } \\
\text { limiting membrane. }\end{array}$ \\
\hline IRBP & AS & 85 & frog cow man & ferritin/EM & $\begin{array}{l}\text { IPS also ensheathed connecting cilium. } \\
\text { None in cytoplasm of cells bordering } \\
\text { IPS. }\end{array}$ \\
\hline IRBP & AS & 86 & monkey & IF. IP. EM & IPS. RIS Cytoplasm of rod cells. \\
\hline IRBP & AS & 87 & ground squirrel & IP. gold/EM & IPS. \\
\hline PABP & AS & 88 & $\operatorname{man}$ & IB. IF & IPS. \\
\hline \multicolumn{6}{|c|}{ Retinal Pigment Epithelium } \\
\hline actin & AS & 91 & rat IS & IF & $\begin{array}{l}\text { Associated with circumferential micro- } \\
\text { filament bundle. }\end{array}$ \\
\hline actin & $\mathrm{Ph}$ & 91 & rat IS & $\mathrm{F}$ & Circumferential microfilament bundle. \\
\hline actin & $\mathrm{Ph}$ & 92 & chick IS & $\mathrm{F}$ & Cortical ring. \\
\hline actin & $\mathrm{Ph}$ & 93 & chick IV & $\mathrm{F}$ & Microfilament arrays. \\
\hline actin & $\mathrm{Ph}$ & 94 & chick IV & $\mathrm{F}$ & Variable, dependent on cell morphology. \\
\hline actin & $\mathrm{Ph}$ & 95 & man IV & $\mathrm{F}$ & Microfilament bundles. \\
\hline actin & As & 96 & chick IS. IV & IF & Circumferential microfilament bundles. \\
\hline actin & AS & 97 & rat IV & IF & $\begin{array}{l}\text { In association with phagosomes. Micro- } \\
\text { filament bundles. }\end{array}$ \\
\hline ATP-ase & AS & 118 & rat IS & IF & $\alpha(+)$ Absent and $\alpha$ present in RPE. \\
\hline $\begin{array}{l}\text { collagen } \\
\text { type IV }\end{array}$ & AS & 108 & chick IS & IF & RPE basement membrane. \\
\hline $\begin{array}{l}\text { collagen } \\
\text { type IV }\end{array}$ & AS & 109 & chick IV & IF & Beneath cells. \\
\hline $\begin{array}{l}\text { desmosomal } \\
\text { components } \\
82 \text { and } 86 \mathrm{kD}\end{array}$ & AS & 102 & chick IS. IV & IF & $\begin{array}{l}\text { Junction complex region. } \\
\text { Similar to vinculin. }\end{array}$ \\
\hline $\mathrm{Fc}$ and $\mathrm{C} 3 \mathrm{~b}$ & & 115 & $\operatorname{dog}$ & rosette & RPE. \\
\hline $\mathrm{Fc}$ and $\mathrm{C} 3 \mathrm{~b}$ & & 116 & rat & rosette & Absent. \\
\hline fibronectin & MAb & 108 & chick IS & IF & Basement membrane area. \\
\hline fibronectin & AS & 109 & chick IV & IF & Beneath cells. \\
\hline fibronectin & AS & 110 & cow IS & IF & Basement membrane area. \\
\hline fibronectin & MAb & 111 & chick IS & IB. IF & Basement membrane area. \\
\hline
\end{tabular}


Table 1 continued

\begin{tabular}{|c|c|c|c|c|c|}
\hline$A g$ & $A b$ & $\operatorname{Ref}$ & Spp & Tech & Localisation \\
\hline fibronectin & AS & 112 & monkey IS & IF. EM & Basement membrane area. \\
\hline fibronectin & AS & 113 & rat IS & EM & Apical microville Golgi-ER. \\
\hline HLA-DR & MAb \& AS & 117 & $\operatorname{man}$ & IF. IP & $\begin{array}{l}\text { Absent in normals. Present in retinitis } \\
\text { pigmentosa. }\end{array}$ \\
\hline $\begin{array}{l}\text { insulin-like } \\
\text { growth factor }\end{array}$ & $?$ & 120 & $\operatorname{man}$ & $?$ & $?$ \\
\hline integrin & MAb \& AS & 111 & chick IS & IB. IF & Basal - lateral surface. \\
\hline keratin & AS & 100 & $\begin{array}{l}\text { various, man } \\
\text { IS IV }\end{array}$ & IF IB & Cytoplasmic filaments. \\
\hline keratin & MAbs AS & 106 & man IS IV & IF.IP.IGS.IB & Cytoplasmic filaments. \\
\hline laminin & AS & 108 & chick IS & IF & Basement membrane. \\
\hline laminin & AS & 109 & chick IV & IF & Beneath cells. \\
\hline laminin & AS & 110 & cow IS & IV & Basement membrane. \\
\hline $\begin{array}{l}\text { mannose-6- } \\
\text { phospate } \\
\text { receptors }\end{array}$ & AS & 119 & rat IS & gold/EM & Plasma membrane. \\
\hline myosin & AS & 91 & rat IS & IF & Circumferential microfilament bundles. \\
\hline myosin & AS & 92 & chick IS & If & Cortical ring. \\
\hline proteoglycans & AS & 108 & chick IS & IF & Basement membrane. \\
\hline proteoglycans & AS & 109 & chick IV & IF & Beneath cells. \\
\hline proteoglycans & MAbs & 114 & rat IS & IF IP & Interphotoreceptor space. \\
\hline $\begin{array}{l}\text { retinoid bind- } \\
\text { ing proteins }\end{array}$ & AS & 121 & rat IS & gold/EM & RPE cytoplasm. \\
\hline $\begin{array}{l}\text { retinoid bind- } \\
\text { ing proteins }\end{array}$ & AS & 122 & cow rat monkey & IF IP IB & RPE. Interphotoreceptor space. \\
\hline spectrin & AS & 92 & chick IS & IF & Cortical ring near membrane. \\
\hline spectrin & AS & 103 & chick IV & IF & Cortex of cell. \\
\hline spectrin & AS & 104 & chick IV & IF & Surface lamina. \\
\hline transferrin & $?$ & 120 & $\operatorname{man}$ & $?$ & $?$ \\
\hline tubulin & AS & 98 & chick IV & IF & Microtubules. \\
\hline tubulin & AS & 99 & rat & IF & Microtubules, normal and dystrophic. \\
\hline vimentin & AS & 94 & chick IV & IF IB & Cytoplasmic filaments. \\
\hline vimentin & AS & 102 & chick IS IV & IF IB & Cytoplasmic filaments. \\
\hline vimentin & AS & 92 & chick IS & IF & Contact rings adjacent to membrane. \\
\hline vimentin & AS & 98 & chick IV & IF & Focal contacts. \\
\hline vimentin & AS & 102 & chick IS IV & IF & Associated with cell junctions. \\
\hline vimentin & AS & 103 & chick IV & IF & $\begin{array}{l}\text { Areas of adhesion cortical band of ad- } \\
\text { hearing junction. }\end{array}$ \\
\hline vimentin & AS & 105 & chick IV & IF & Focal contacts. \\
\hline Others & & & & & \\
\hline$?$ & 9 MAbs & 123 & chick & IF & RPE. \\
\hline $72 \mathrm{kD}$ protein & MAbs C6,C8 & 124 & bovine & IB & Membrane. \\
\hline $42 \mathrm{kD}$ protein & MAb & 125 & $\begin{array}{l}\text { frog rat cow } \\
\text { chick monkey man }\end{array}$ & IP & RPE. \\
\hline$?$ & $\begin{array}{l}\text { MAbs RET- } \\
\text { PE1 } \\
\text { MAbs RET- } \\
\text { PE2 }\end{array}$ & 126 & rat & IF & RPE. \\
\hline
\end{tabular}

Table I

This table summarises the antigens of the outer retina identified using immunocytochemical methods. The abbreviations used are: Ab: antibody, Ag: antigen, AS: antiserum. EM: electron microscopy, F: fluorescence, IB: immunoblotting, IF: immunofluorescence, IGS: immunogold silver, IP: immunoperoxidase, IS: in situ, IV: in vitro, MAb: monoclonal antibody, PAP: immunoperoxidase using peroxidase-anti-peroxidase conjugate, $\mathrm{Ph}$ : fluorescent phallotoxin, Ref: reference, Spp: species, Tech: Technique. 
phosphorylation and signal transduction and a number of contractile or filamentous proteins. Other retinal proteins may assume a structural or supportive function. A great deal of our understanding of the roles of these retinal proteins stems from their localisation. Immunochemical and cytochemical techniques played a vital role in unravelling the location and chemical structure of these proteins. These immunological findings are briefly discussed.

\section{Rhodopsin}

The outer segment of rods contains stacks of flattened discs formed by lipid bilayers which provide a matrix for the protein molecules. These discs are not continuous with the plasma membrane of rod outer photoreceptors, but are connected to it by filamentous structures. ${ }^{10-11}$ Cone photoreceptors differ from rods in that discs generally maintain continuity with the plasma membrane. ${ }^{11}$ The visual pigment rhodopsin is the major protein of the rod outer segment (ROS). Rhodopsin is an intrinsic glycoprotein which spans the disc membrane thickness, crossing the membrance interface several times. ${ }^{12}$ Immunocytochemical techniques, on the light microscopic level, have helped in the localisation of rhodopsin on both the discs and plasma membrane. This observation was made almost two decades ago when Dewey et al. ${ }^{13}$ used polyclonal anti-rhodposin antiserum to localise rhodopsin on the frog ROS. Jan and Revel ${ }^{14}$ have confirmed the localisation of rhodopsin on both sides of discs and plasma membrane of mice and bovine ROS using the immunoperoxidase technique for analysis by transmission electron microscopy. Rhodopsin was also visualised in small quantities along the connecting cilium and the plasma membrane of the rod inner segment (RIS). Using biotinylated sheep anti-opsin antiserum and avidin ferritin markers, Papermaster and co-workers ${ }^{15}$ reported similar localisation of rhodopsin in frog photoreceptors. Recent advances in immunocytochemistry have made possible the use of monoclonal antibodies in the localisation of epitopes on thin sections. A monoclonal antibody to rhodopsin (RET-P1) was used in an indirect immunofluorescent labelling of rat photoreceptor cells. It showed intense labelling of the entire photoreceptors with the exception of the synaptic ending in the outer plexiform layer. ${ }^{16,17}$ Closer examination of the rat retinal sections showed reaction in the cell bodies, outer and inner segments of rods but not cones. This antibody also reacted with a group of photoreceptors, in retinal sections, from the tiger salamander. Another monoclonal antiopsin antibody (RHO-C7), whose epitope is in the $\mathrm{N}$-terminal region of the rhodopsin molecule has been found to label only the outer segment of rat retina. ${ }^{17}$

However, different epitopes of the rhodopsin molecule have different immunocytochemical localisation patterns. This could be clearly verified by ultrastructural examination using immunoelectron microscopy. This was well demonstrated when RET-P1 antibody (using PAP staining technique) showed dense labelling of the plasma membrane of both outer and inner segments of rod photoreceptor. ${ }^{17} \mathrm{~A}$ more diffuse reaction was also evident near the edges of the photoreceptor discs and in the peripheral cytoplasm of the inner segment. Staining over the external face of the plasma membranes of the outer and the inner segments was also seen when a ferritin-conjugated marker was used. ${ }^{17}$ In contrast, RHO-C7 antibody was found to label only the external face of the plasma membrane of photoreceptor outer segment and occasionally the surface of the inner segments.

A more detailed ultrastructural study was described by Molday and co-workers, using a panel of monoclonal antibodies to rhodopsin. Various degrees of labelling of the external surfaces of the rods plasma membrane was noted when monoclonal anti-opsin antibodies, specific to the $\mathrm{N}$-terminal region were used. Visualisation by an immunogold-dextran marker, on gluteraldehyde fixed bovine retinas, revealed that only one monoclonal antibody (4D2; specific to fragment 1 at the $\mathrm{N}$-terminus of rhodopsin) exhibited dense labelling of the external surface of the ROS plasma membrance. ${ }^{18}$ Another monoclonal antibody (4A2) which recognised the same F1 fragment showed a marked reduction in its labelling of the external surfaces of the plasma membrane. In contrast, three other $\mathrm{N}$ terminus-specific monoclonal antibodies (4A3, 3D3 and 5A3) exhibited no labelling of the rod outer or inner segments. Treatment of fixed retinas with ethanol followed by rehydration, or treatment with detergent (saponin) and sodium borohydride, seemed to increase the accessiblity of antigen sites. All but one (3D3) of the above 
five monoclonal antibodies reacted more intensely. ${ }^{18}$ Gold-dextran particles were observed along the external surface of bovine ROS when $5 \mathrm{~A} 3$ and $4 \mathrm{~A} 3$ were used. An increase in the intensity of labelling was found when 4D2 or $4 \mathrm{~A} 2$ monoclonal antibodies were employed. Antibody 3D3 again failed to react with ROS under any of the above conditions. On a thin section of frog ROS, 4D2 showed intense labelling of the red ROS. The other monoclonal antibodies exhibited significantly lower reaction. Green ROS, cone outer segments (COS) and rod inner segments (RIS) all reacted slightly with all five monoclonal antibodies. ${ }^{18}$

On the other hand, a C-terminus-specific monoclonal antibody, 1C5, did not show any labelling of the external surface of ROS under any of the above conditions. Using antibodies on Lowicryl-embedded thin sections of the bovine retina, C-terminus-specific (1D4), or $\mathrm{N}$-terminus specific (4D2 and 5A3) monoclonal antibodies, strongly labelled the ROS and slightly the inner segment and the connecting cilium. Monoclonal antibodies 1D4 and 2C1 (C-terminus-specific) reacted with both red, and more intensely, the green frog ROS on thin sections. ${ }^{18}$ Other Cterminus specific anti-bovine monoclonal antibodies, $3 \mathrm{~A} 6$ and $1 \mathrm{C} 5$, exhibited no cross reactivity with frog ROS, COS and RIS. Only one C-terminus-specific antibody, 3D6, showed strong labelling of the bovine and frog COS as well as ROS. No reaction was observed in the inner segments. ${ }^{18}$

This account demonstrated the power of using specific monoclonal antibodies in association with different pre- and post- embedding treatment strategies.

\section{$S$-Antigen}

S-Antigen, a soluble retinal protein, was isolated and characterised for the first time by Wacker et al. ${ }^{19}$ The protein has an apparent $\mathbf{M}$. wt. of $50 \mathrm{kD}$ on SDS-polyacrylamide gels ${ }^{20}$ and has stimulated a great deal of interest due to its ability to induce experimental autoimmune uveoretinitis (EAU) in various animal species (for review see Faure et al. ${ }^{21}$ Gery et al. ${ }^{22}$ ) Recently, Pfister et al. ${ }^{23}$ identified S-Ag as the $48 \mathrm{kD}$ protein which binds specifically to photoexcited and phosphorylated rhodopsin and inhibits cGMP hydrolysis. This makes it an important part of the phototransduction process of the photoreceptor cells.
The localisation of S-Ag by immunocytochemistry has been demonstrated in both the photoreceptor cells and the pineal glands. ${ }^{24-26}$ Using indirect immunofluorescent staining and an antiserum to bovine $\mathrm{S}-\mathrm{Ag}$, Wacker and coworkers $^{19}$ found the protein in the entire photoreceptor cells and the staining pattern suggested an association with the plasma membrane. $^{27}$ No specific fluorescence was detected in the RPE or choroid. Yajima et al. ${ }^{28}$ obtained similar results by using direct immunoperoxidase staining of rabbit retinas. At the electron microscopic level they found immunoreaction on both sides of the disc membranes of the outer segment with particles distributed in a pattern symmetrical to that of the membrane. Positive reaction was also shown in the plasma membrane of the outer segment. Some labelling was found in the tips of the outer segments before phagocytosis but not after. However, studies on $30 \mathrm{~h}$ light adapted rabbit retinas showed abundant reaction products in the cytoplasm of the RPE cells and also in Bruch's membrane and the endothelium of choriocapillaris. ${ }^{29}$ The outer segments of the photoreceptor cells showed swelling and destruction of the disc membranes and contained only a little reaction product. On the other hand, Broekhuyse et al. ${ }^{30}$ found, at the EM level and using $24 \mathrm{~h}$ light adapted rat retinas, that the immungo-gold particles were seen in the ROS over the areas containing stacked discs. The plasma membranes were only slightly labelled.

Using an antiserum to $\mathrm{S}-\mathrm{Ag}$ and the peroxidase antiperoxidase immunohistochemical technique on fixed rat retina, Uusitalo et al. ${ }^{31}$ found, at the light microscopic level, intense reaction in the outer segment of the photoreceptor layer with immunostaining around the cell bodies of the outer nuclear layer. Their EM studies showed immunoreactivity mainly in the inner surfaces of disc membranes of the rods and its plasma membranes. Plasma membranes of outer nuclear layer also showed a positive reaction. However, studies on the localisation of S-Ag in human retinas, McKechnie et al. ${ }^{32}$ showed no specific staining of the ROS plasma membrane. They used fixed sections embedded in Lowicryl K4M, cut and treated with anti-bovine $S$ antisera and protein A/gold complex. Specific labelling was observed in the proximal portion of the ROS which diminished towards the top of the ROS. 
Positive staining was distributed uniformly showing preferential deposition on the ROS disc membranes. The connecting cilium was also labelled but no reaction was seen in rod spherule, outer nuclear layer or the inner segment.

Recent developments in MAb technology has allowed the isolation of $\mathrm{Abs}$ to $\mathrm{S}-\mathrm{Ag}$ by various groups. ${ }^{33-37}$ MAbs allow the study of different epitopes of the protein, their location by immunocytochemistry, and phylogenic distribution. Faure and co-workers isolated six mouse MAbs to S-Ag., four of which stained ocular tissues from various classes of vertebrate and invertebrates. ${ }^{36}$ They labelled the entire photoreceptor cell, excluding the nucleus. This indicates the presence of distinct epitopes even in distant species. A similar staining pattern of the photoreceptors was shown by Donoso and coworkers. $^{35}$ They reported two MAbs to $\mathrm{S}-\mathrm{Ag}$ characterised by the ELISA and immunoblotting techniques. However, only one of them, MAb A9-C6, reacted on fixed embedded tissue sections of vertebrate retinas including human, bovine, guinea pig, mouse and the developing rat. Fluorescent and immunoperoxidase staining techniques were used.

At the EM level, using two mouse MAbs and indirect autoradigoraphy, Das et $\mathrm{al}^{33}$ reported the localisation of S-Ag in fixed bovine explants. The protein was shown in the apical portion of the ROS with the use of MAb RSA 1/83. The second MAb RSA 2/83 showed the Ag both in the inner and outer segment of the rod cells.

More recently, a rat monoclonal antibody ( $\mathrm{S}$ $2.4 \mathrm{CS}$ ) produced against bovine $\mathrm{S}-\mathrm{Ag}$ and characterised by immunoblotting, was shown, by EM localisation, to uniformly label the ROS disc membranes of human and pig photoreceptors. ${ }^{37}$ Labelling was also seen in the perinuclear area and over the connecting cilium. Newly phagocytosed ROS membrane in the apical region of the cell was also labelled. Those in deeper areas of the cell showed less label. It was suggested that the antigenicity of the protein decreased as the digestion of the RPE proceeded.

cGMP-PDE

Hydrolysis of cGMP by cGMP-phosphodiestrase (cGMP-PDE) is one of the early events that occur in retinal rod cells, following illumination. ${ }^{38}$ The frog cGMP-PDE has a molecular weight of $240 \mathrm{kD}$ while the mammalian enzyme has an apparent M.wt. of $170-185 \mathrm{kD}$ and is composed of three subunits; two catalytic, $\alpha$ and $\beta$, of 88 and $84 \mathrm{kD}$ and the inhibitory $\gamma$-subunit of approximate M.wt. of 10-13 kD.

Specific rabbit antisera to bovine PDE and its inhibitory $\gamma$-subunit were used to determine their effect on enzyme activity. ${ }^{39}$ The antisera also reacted with immmunologically-related polypeptides in pig, rat, frog and fish using the immunoprecipitation technique. Two monoclonal antibodies were produced against bovine retinal cGMP-PDE (ROS-1 and ROS-2). Both ROS-1 and ROS-2 reacted with one polypeptide (corresponding to the PDE) by immunoblotting. ${ }^{40}$ Using the indirect immunofluorescent technique and ROS-1 antibody, it was possible to localise the enzyme's antigenic determinant to both rod and cone outer segments of the bovine retina. Immuno-adsorption technique, using ROS-1 monoclonal antibody, demonstrated the presence of polypeptides of similar mobility to bovine cGMP-PDE in gold fish, mammals (human and rat) and frog retinas. ROS- 1 and ROS- 2 absorbed all the three $(\alpha, \beta$ and $\gamma)$ polypeptides of bovine PDE. Indirect immunofluorescent staining with ROS-1 antibody on frozen sections of human retina revealed labelling in both rod and cone photoreceptor outer segments. The same pattern was seen in other vertebrate retinas with no reaction being evident in the inner segments. ${ }^{40}$ In the primate retina, the long slender outer segments of the foveal cones were also stained with ROS $-1 .{ }^{40}$ Another monoclonal antibody to frog PDE failed to block light-activated guanine nucleotide binding nor did it inhibit the PDE activity. This suggested that the antibody did not bind the functional moiety of the enzyme. ${ }^{41}$

Ultrastructural localisation of cGMP-PDE using affinity purified anti-bovine PDE antiserum, on Lowicryl K4M embedded sections, indicated the presence of the enzyme, specifically in rods and mainly in the outer segment region. Some labelling, in some sections, was also observed in the lumen of the connecting cilium and RIS at the Golgi apparatus. ${ }^{42,43}$ The biotin-avidin immunoferritin labelling was absent from cone photoreceptor cells.

G-Protein (Transducin ' $T$ ") complex. ${ }^{42}$

Several retinal proteins bind strongly to the visual pigment rhodopsin in the disc membrane, 
following illumination (reviewed by Kuhn. ${ }^{44}$ ) Amongst the proteins that bind to rhodopsin in a light-dependent manner is the G-protein complex. It consists of three polypeptide chains, $\alpha, \beta$ and $\gamma$ of apparent molecular weights of 39-40 kD, 36-37 $\mathrm{kD}$ and 6-8.5 kD respectively. ${ }^{45,46}$

Rabbit antiserum (GI-2) to bovine retinal $\alpha$ subunit was tested for its reactivity with retinal proteins, using the immunoblotting technique. ${ }^{47}$ The antiserum reacted specifically with the $\alpha$ subunit of transducin and no cross reactivity was noted with other bovine retinal proteins. It also reacted with a protein band from chicken retina that had the same electrophoretic mobility as $\alpha$ transducin from bovine retina. Using the indirect immunofluorescent technique, the antiserum labelled only the photoreceptor cells layer of frozen sections of chicken, bovine, monkey and human retinas. ${ }^{47}$ It was also found that rods but not cones were heavily labelled with this antibody. This may suggest that the $\alpha$-subunit structure of cones differ from that of the rods. It is also possible that rod and cone cells utilise different phototransduction mechanisms.

Eleven monoclonal antibodies to frog Gprotein complex were found, by immunoblotting, to recognise the $\alpha$-subunit (40 kD) only and not the $\beta$ or $\gamma$-subunits. ${ }^{48}$ Two of these antibodies, using the indirect immunofluorescent technique on isolated frog ROS (fixed, either in light or in dark, with paraformaldehyde), showed uniform fluorescence along the whole isolated rod outer segment. Ultrastructural localisation with other monoclonal antibodies to the G-protein complex, has not yet been presented.

LIMP (ROS 1.2)

Although disc membranes of rod photoreceptor cells are densely packed with rhodopsin, another large intrinsic membrane protein (LIMP), of apparent molecular weight (on SDS-PAGE) of 220-240 kD in cattle and human and $290 \mathrm{kD}$ in frog, was found to be continuously (and may be synchronously with rhodopsin) synthesised and assembled into disc membrane.$^{49-50}$ This large glycoprotein was specifically localised by EM immunocytochemistry (using retina embedded in gluteraldehyde cross-linked BSA and indirectly visualised by ferritin-conjugated antibody) to the incisures of frog ROS discs and to the disc margins. ${ }^{51}$ The incisures divide the disc into lobes (Figure 1). Recent ultrastructural localisation, using the same purified antiserum on frog outer segments, showed that the immuno-labelling was on the short incisures and margins of red and green ROS and the margins of COS lamellae. ${ }^{52}$ Labelling of the interincisures surface of all photoreceptor classes was also noted by using higher antibody concentration.

Monoclonal antibodies to bovine LIMP were also used for its ultrastructural localisation. ${ }^{53}$ Immunoferritin labelling with these antobodies (3D12 and 4B2) and transmission EM, confirmed the location of the protein in the margins of bovine ROS discs and its exposure on the cytoplasmic disc surface. Both monoclonal antibodies recognised different sites of the protein.

\section{Peripherin}

The use of monoclonal antibodies and the immunoblotting technique helped in unveiling the presence of yet another membrane protein (M. wt. $33 \mathrm{kD}$ ) that is usually masked under the thick abundant band of rhodopsin when bovine ROS are analysed by SDS-PAGE ${ }^{1}$ (see Figure 2).

Because this protein was localised by immunocytochemistry on the rim of ROS discs (Fig 4) it was termed "peripherin" by Molday and coworkers. Immunogold labelling of morphologically intact isolated discs, prepared by mild trypsinisation of the ROS fraction, confirmed the localisation of this protein at the rim region of discs. Immunogold dextran labelling of ROS sections embedded in Lowicryl resin indicated that this protein is located around the periphery of ROS organelle where the discs come in close contact to the ROS plasma membrane ${ }^{1}$ (see Figure 4).

\section{Cytoskeleton and structural proteins}

Immunolocalisation techniques have played a vital role in understanding the distribution of structural and membrane associated proteins of the outer retina. Localisation of a number of these filamentous or supportive proteins was made possible by using specific antibodies. These techniques are particularly powerful when the protein(s) are present in small amounts. The following is a brief account of the majority of identified components:

(1) Actin: It is now accepted that actin is present in muscle as well as in non-muscle cells. ${ }^{55}$ Actin appears to have a cytoskeletal or struc- 
tural function, in addition to its contractile role. In the ROS of the retina, actin bundles are thought to play a vital role in the contractile process of rods and cones in addition

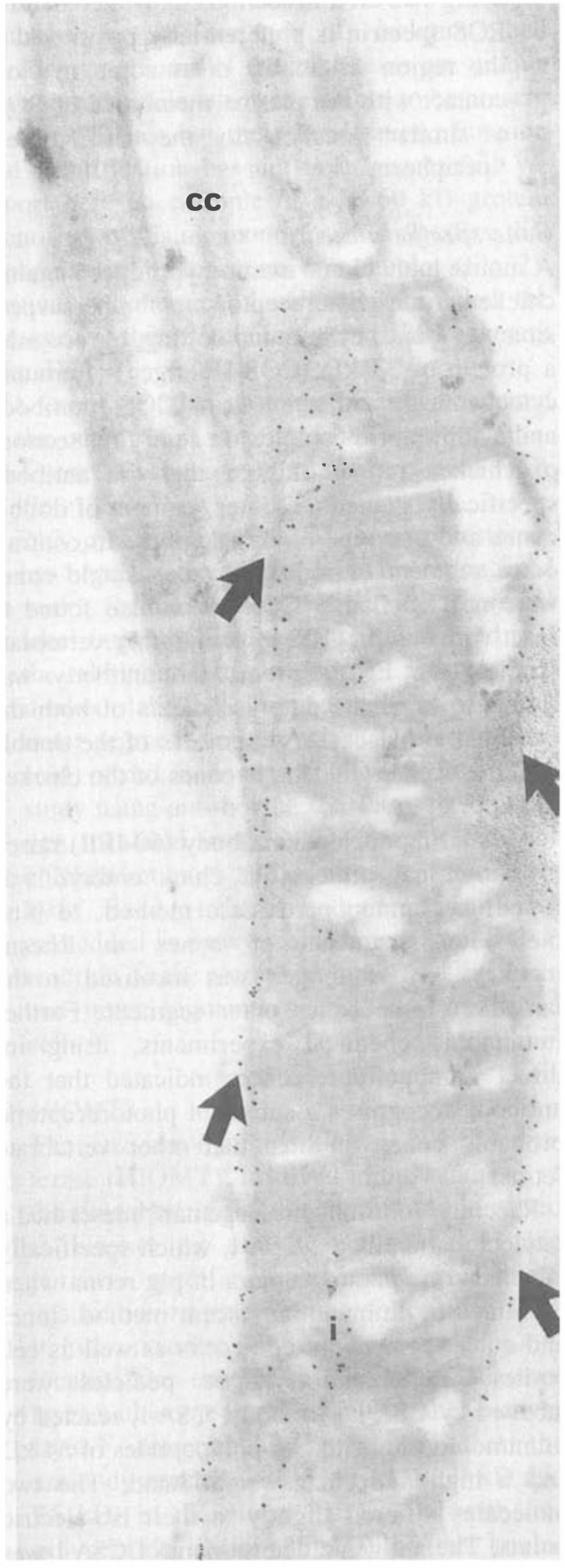

to its role in the process of shedding and phagocytosis by pigment epithelial cells. ${ }^{56}$

Immunocytochemical localisation of actin in frog retina, fixed and embedded in aldehyde cross-linked serum albumin, showed heavy labelling in the apical pigment epithelial cell processes and in the calycal processes of photoreceptor cells, which are the microvillus-like projections that arise from the inner segment and extend alongside the basal outer segment. ${ }^{57}$ Actin was also found, in large quantities, in the connecting cilium (distal area at the site of outer segment disc formation) of both rods and cones using affinity purified rabbit antiserum to chicken gizzard actin, visualised by biotin-avidin-ferritin marker on albumin embedded retinal sections. Labelling with anti-actin was also observed below the new discs in rods while no reaction was noted in the plasma membrane and the interior of the connecting cilium or the remainder of outer segment. Further EM localisation of actin in mammalian retinas, aldehyde fixed and embedded in Lowicryl $\mathrm{K} 4 \mathrm{M}$, was recently described. Thin retinal sections were allowed to react with anti-actin antiserum by the indirect immunoferritin method. ${ }^{58}$ Again actin was localised in the distal cilium of rat, cow, monkey and human photoreceptors. This suggested that an actin-mediated contractile mechanism may also regulate outer segment morphogenesis in vertebrate photoreceptor cells. It was also noted that the anti-actin, labelled the bundle of filaments within photoreceptor calycal processes extending into the inner segment subjacent to the plasma membrane. ${ }^{58}$

Fig. 4. Post embedding EM immunocytochemistry using Lowicryl K4M embedded bovine retina. The section has been incubated with a monoclonal antibody (ROS 4A2), which on immunoblotting recognises a polypeptide with a molecular weight of approximately $32 \mathrm{kD}$. Binding of the antibody has been demonstrated using $10 \mathrm{~mm}$ diameter colloidal gold conjugated with goat anti-mouse immunoglobulin. The antigen appears to be localised at the margins of the outer segment of the photoreceptor (arrows). The staining at (i) is probably following the line of an incisure. (cc) connecting cilium. The localisation at the margins of the outer segment and the apparent molocular weight of the antigen suggest that this antibody recognises peripherin $(x 30,000)$. 
(2) Tubulin: Tubulin is another major cytoskeletal protein found primarily in the cilium of retinal photoreceptors. Roof and Applebury ${ }^{59}$ used anti-tubulin for the immunolocalisation of the protein in isolated frog outer segments, using the indirect immunofluorescent staining method. It was found that the labelled ciliary microtubules can reach distally to the point near the end of the outer segment. Recently, Kaplan et $\mathrm{a}^{60}$ used a monoclonal anti $\alpha$-tubulin antibody followed by a Texas Red fluorophore second antibody to demonstrate the extent of microtubules in isolated frog ROS (fixed with paraformaldehyde). It was possible, by fluorescent microscopy, to visualise the labelling which extended to slightly over half the length of the ROS on diurnal light cycle. Although frog ROS kept in a constant darkness for 3-4 weeks are longer than those maintained on cyclic lighting, the distribution of fractional lengths of anti-tubulin labelling of ciliary microtubules was the same. In fewer than $15 \%$ of rods the immunolabelling extended into the distal region of the outer segment where disc membrane shedding occurs. ${ }^{60}$

(3) Calmodulin and Calmodulin binding protein: Calmodulin is present in vertebrate ROS in very low quantities. However, it was possible to localise this protein by immunofluorescence using anti-calmodulin antiserum. The labelling was restricted to a stripe in the ciliary body of ROS. ${ }^{59}$

A number of polypeptides were found to bind calmodulin in a $\mathrm{Ca}^{2+}$-dependent manner. One of these proteins of $240 \mathrm{kD}$, was found in cattle and toad retinas. Using antiserum to the mouse brain fodrin (a spectrin like actin- and calmodulin-binding protein) it was possible to show, by immunoblotting, that this antibody cross reacted with the $249 \mathrm{kD}$-calmodulin binding protein. In toads, the fodrin-like $240 \mathrm{kD}$ polypeptide was found to be distinct from the "large intrinsic membrane protein (ROS 1.2)". 59

(4) Spectrin-like protein. Wong and Molday ${ }^{61}$ reported the presence, in bovine photoreceptor cells, of a $240 \mathrm{kD}$ polypeptide related to the $\alpha$-subunit of red blood cell spectrin. Its properties and molecular weight were confirmed by immunoblotting, using a monoclonal antibody (4B2). Biochemical studies showed that it was not an integral membrane protein but a tightly membraneassociated one. Ultrastructural localisation, using 4B2 on thin sections, indicated that the ROS spectrin is preferentially positioned in the region where the discs come in close contact with the plasma membrane of ROS, a similar location to the rim protein "peripherin".61

\section{Cone specific proteins}

A mouse monoclonal antibody produced against chicken crude photoreceptor membrane suspension was found, by immunoblotting, to recognise a protein of $33 \mathrm{kD}$ (COS-1 antigen). Immunocytochemical localisation using COS-1 antibody and avidin-biotin complex on semi-thin sections of chicken retina, showed that the antibody specifically stained the outer segment of double cones and one type of single cones. In contrast outer segment of rods and other single cones were not labelled. ${ }^{62}$ COS-1 was also found to react with certain COS of many other vertebrate species. On EM sections, the antibody was shown to label the outer segments of both the principal and accessory members of the double cones as well as the single cones of the chicken retina. ${ }^{62}$

Another monoclonal antibody (50-1B11) raised to the retinal proteins of chick embryo was found, by immunoperoxidase method, to bind the outer segments of cones in Rhesus monkeys. ${ }^{63}$ The antigen was localised in the lamellae of the cones outer segment. Further immunohistochemical experiments, using indirect immunofluorescence, indicated that the antibody recognises a subset of photoreceptors, probably cones, in man and other vertebrate retinas.

Recently, Johnson and Hageman ${ }^{64}$ described a monoclonal antibody, CSA-1, which specifically labelled cone photoreceptors in pig retina when examined by immunofluorescent method. Inner and outer segments of cone cells as well as cell bodies, axons and synaptic pedicles were labelled by CSA-1. Antibody, CSA-1, reacted by immunoblotting with two polypeptides of $54 \mathrm{kD}$ and a high molecular weight band. The two molecules differed slightly in their iso-electric points. The antigenic determinant of CSA-1 was found to be a galactose-containing carbohydrate 
moiety as judged by enzymatic digestion. ${ }^{64}$ Miscellaneous

A number of other proteins are found in the retina. Their characterisation is not well achieved, partly due to the lack of a known function or a method of isolation and purification. Some of these proteins are unique to the retina while others are known to be present in other tissues but their localisation, function and identification has not been successful. We report here an example of a $58-60 \mathrm{kD}$ protein identified by using monoclonal antibodies that recognise its epitopes on immunoblot (Fig 2). Immunocytochemical localisation revealed the presence of this protein in the rod outer segment (Fig 3).

A few of the other proteins and enzymes found in the outer retina are listed below:

(1) Cyclic nucleotide phosphodiesterase (CN Pase)

2',3'-cyclic nucleotide 3'-phosphodiesterase has been localised in fresh bovine retina fixed with formaldehyde. Immunocytochemical localisation by light microscopy showed that the rabbit antiserum used in the indirect PAP method labelled the photoreceptors in the outer segment and an external region (ellipsoid) of rod inner segment layer. ${ }^{65}$ In another study using anti-bovine $\mathrm{CN}$ Pase, the antigen was localised in the photoreceptor layer of chicken retina. ${ }^{66}$ EM sections of gluteraldehyde fixed, treated with antiserum and embedded in epoxy resin showed strong PAP reaction on the plasma membrane of the inner and outer segments of both rod and cone cells. ${ }^{66}$

\section{(2) HIOMT}

The enzyme hydroxyindole-O-methy transferase (HIOMT), involved in the synthesis of the pineal hormone, melatonin was localised in bovine, rat and human retinas. Using purified specific rabbit antiserum raised against bovine pineal extract followed by PAP, it was possible, by light microscopy, to localise the enzyme in the outer segment layer with some labelling in the inner nuclear layer. ${ }^{67}$ Immunoblotting showed that the antibody reacted with two bands $(39 \mathrm{kD}$ and $25 \mathrm{kD}$ ) in the pineal extract and with one polypeptide chain $(25 \mathrm{kD})$ of the bovine retinal extract.

\section{(3) Visinin and Calbindin}

Visinin (M wt $24 \mathrm{kD}$ ) was first isolated from chick retina in $1983 .{ }^{68}$ Antiserum against visinin of the chick retina also labelled the photoreceptor cells of human, cat, frog and crab retinas. ${ }^{69}$ Staining of cone cells was clearly evident in the photoreceptor layer while rods showed barely detectable labelling in the direct immunofluorescent microscopy. Recently, Pasteels et al, ${ }^{70}$ presented evidence based on immunoblotting cross reactivity between visinin and calbindin, a $27 \mathrm{kD}$ vit-Ddependent calcium binding protein, that these two proteins are the same, though the latter occurs in brain and other tissues at a slightly higher molecular weight. Antiserum to calbindin again stained cone cells in pigeon and chick retinas, using the PAP method and light microscopy. Other retinal cells were also labelled but to a lesser extent. ${ }^{70}$

\section{(4) CSAD}

The taurine synthesising enzyme, cysteine sulphinic acid decarboxylase (CSAD) was localised in the retina using thin sections of gluteraldehyde fixed, antiserum-treated and embedded in low gelling-temperature agarose. Peroxidase labelling, visualised by $\mathrm{EM}$, was found in rat retinal neuronal types and their processes including the photoreceptor rod and cone cells. ${ }^{71}$ The staining was clearly evident in certain cone pedicles and rod spherules. Other cells (like ganglion cells) also showed heavy staining.

\section{(II) Interphotoreceptor Matrix}

The IPM occupies the area between the neural retina and the RPE. This matrix lacks collagen and fibronectin and contains proteins and glycosaminoglycans (GAGs). Proteins constitute $98 \%$ of the soluble fraction of the IPM compared to the $2 \%$ composed of GAGs. ${ }^{82-83}$

The IPM has a strategic location and could have various physiological roles including the mediation of the transport of nutrients and vitamins such as vitamin $A$ and vitamin $E$.

Most of the soluble IPM proteins appear to be synthesised by either the RPE or photoreceptor cells. ${ }^{73}$ The major protein of the IPM was found to be the interphotoreceptor retinoid binding protein (IRBP). ${ }^{74}$ 


\section{IRBP}

Interphotoreceptor (or interstitial) retinoid binding protein (IRBP), is a large glycolipoprotein of the interphotoreceptor matrix. It has an apparent $\mathrm{M}$. wt. of $140 \mathrm{kD}$ as assessed by SDS-polyacrylamide gels. This protein has been shown to be the only retinoid-binding protein in the IPM ${ }^{72,75-76}$ and could be involved in the transport of vitamin A between the RPE and retinal photoreceptors. ${ }^{77-78}$ Accumulating evidence indicates that the rod photoreceptor cells are the site of its biosynthesis. ${ }^{79-81}$ This IRBP has been well characterised, and localised mainly to the IPM. Using light and electron microscopy, Bunt-Milam and $\mathrm{Saari}^{76}$ found IRBP in the space surrounding photoreceptor outer segment and the apical surfaces of inner segments, with the heaviest labelling in the line corresponding to the RPE apical surface. This was resolved on the electron microscopic level to the IRBP coating the RPE microvilli. The label was also found around rod and cone inner segment and in the intralamellar spaces of the COS. The Müller cell microvilli were also heavily stained. Fong et $\mathrm{al}^{82}$ using $\mathrm{LM}$ and fluorescent or peroxidase staining on fixed human tissues embedded in gelling agarose, demonstrated the presence of IRBP in the space surrounded by the epical surfaces of the RPE cells and in the region of the external limiting membrane (ELM). No IRBP was detected in the inner segments of photoreceptor cells. Similar results were found in a rat retina. ${ }^{83-84}$ Recently, Schneider et $a^{85}$ localised IRBP, by EM microscopy in bovine, human and frog retinas, using affinity purified rabbit and bovine IRBP and visualised by avidin-ferritin or biotinylferritin markers. Tissues were fixed then embedded in Lowicryl K4M. The protein was found, unevenly distributed, in the IPM. The highest labelling was in areas immediately adjacent to photoreceptor plasma membranes or PE processes. Cytoplasm of rods and cones was unlabelled if cells were intact. This is in contrast to the result of Bunt-Milam and Saari ${ }^{76}$ who found labelling of IRBP in the COS. Schneider et $\mathrm{al}^{85}$ also found labelling surrounding the connecting cilium. No label was detectable within photoreceptor IS, pigment epithelium or Müller cells. However, Rodrigues et $\mathrm{a}^{86}$ found immunostaining of IRBP at the EM level in monkey rod cell cytoplasm and inner segments.
No immunoreactivity was found in Müller cells or the fovea where there was no staining of the CIS or COS. Anderson et al ${ }^{87}$ found IRBP in the cone-dominant ground squirrel retina. Hollyfield et al $^{80}$ also found immunoreactivity in the IPM of the fovea of human retina.

Peanut agglutinin-binding protein $(P A B P)$ :

This large glycoprotein of unknown function was identified and purified from human retina using its lectin-binding property. Rabbit antiserum to the affinity purified protein was used to confirm its molecular weight (135 kD on SDS-PAGE) by immunoblotting and its distinction from IRBP which binds Con A lectin. ${ }^{88}$ Fluorescent microscopic localisation of the antigen in human retina indicated that it is an interphotoreceptor matrix component apparently around both rod and cone cells. ${ }^{88}$

\section{Antigen specific to the Cones' Sheath}

Using a panel of monocolonal antibodies to various unsaturated glycosaminoglycans, it was possible to identify chondroitin-6-sulphate (C-6-S) as the specific component of primate cone matrix sheath. This was demonstrated by indirect immunofluorescent technique on sections of primate retina. ${ }^{89}$

\section{(III) Retinal Pigment Epithelium}

Immunochemical studies have been conducted on RPE cells both in situ and with cultured cells. A large proportion of this work concerns the cytoskeletal elements of chick RPE. In culture embryonic chick RPE continues to differentiate to produce cells of very similar morphology to those found in vivo. Usually the cells appear as colonies with the cells in the centre having a morphology similar to the in vivo appearance. Toward the edge of the colony the cells express an undifferentiated, well spread morphology and develop large areas of cell-substrate adhesion.

The main elements of the cytoskeleton, actin $^{91-97}$ tubulin $^{93,98,99,103,104}$ and intermediate filaments $^{94,98,100}$ have all been shown to be present. In situ there is considerable cytoskeletal specialisation associated with the zonula adherens region of the junctional complex (JC), the circumferential actin bundles. ${ }^{91,96}$ The microfilament bundles are present in chick RPE in situ and in culture in the differentiated central region of cell colonies. Circumferential microfilament bundles (CMB) have also been demonstrated in rat RPE in situ and are seen by 
electron microscopy in the in situ RPE of all mammalian species studied. In primary culture, adult mammalian RPE adopts a polygonal appearance, similar to its in vivo appearance, and circumferential microfilament bundles do appear to be present. ${ }^{101}$ However, this morphology is usually lost on passage of the cells. A number of cytoskeletal associated proteins are localised in the region of the circumferential microfilament bundle. Vinculin, a Mwt $130 \mathrm{kD}$ protein is closely associated with the membrane. It may be attached to a membrane lipid or to an integral membrane protein. ${ }^{92,102,103}$ Actinin (Mwt $190 \mathrm{k}$ ) and spectinin also localise to this area $^{91,92,103,104}$ ). All these proteins are thought to be involved in the attachement of actin microfilaments to the membrane. Myosin has also been detected in association with the CMBs. ${ }^{91}$ In the well spread cultured chick RPE cells these proteins are associated with regions of focal cell adhesion and microfilament bundles. ${ }^{98,103,105}$

In the case of intermediate filaments the RPE might be expected to express cytokeratins as a reflection of its epithelial character. However, the nature of the intermediate filaments possessed by the RPE appears, at present, to be species dependent. It is known that chick RPE

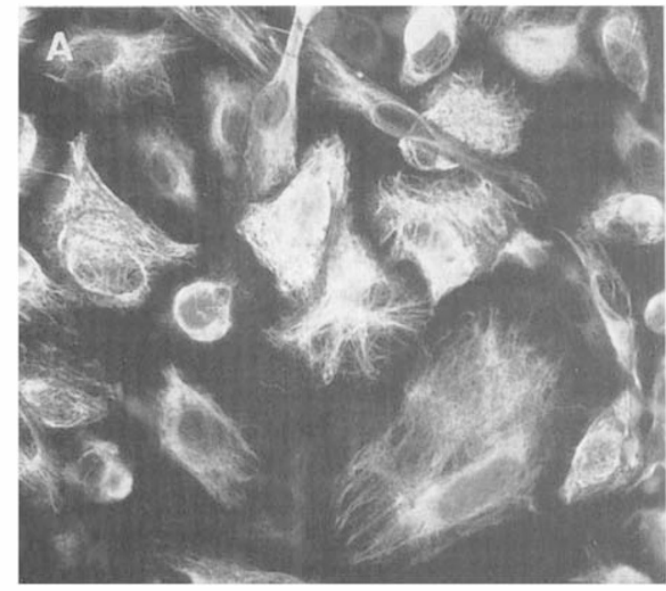

lacks cytokeratins and expresses vimentin. ${ }^{102}$ Human RPE and that of other mammalian species appears to show co-expression of vimentin and cytokeratins both in in situ and in vivo, 100,106 In human RPE the cytokeratins detectable are characteristic of simple or glandular epithelia (Fig. 5). Following the numerical classification system of Moll et al $1982^{107}$ numbers 5, 6, 7, 8, 18 and 19 have been identified by immunoblotting and immunocytochemistry. ${ }^{106}$ Antibodies to some desmosomal components, (the 92 and $86 \mathrm{kD}$ proteins) have been shown to react with the chick RPE but true desmosomes appear to be absent. ${ }^{102}$ The situation with regard to mammalian RPE possessing desmosomes is unclear, particularly in light of the cytokeratin immunoreactivity of human but not chick RPE. ${ }^{100,106}$

The RPE cells are attached to Bruch's membrane by their basal surface and number of basement membrane protein, and basement membrane associated proteins, have been identified in this area. The basement membrane components, type IV collagen ${ }^{108,109}$ and laminin ${ }^{108,109,110}$ have been shown to be present. Fibronectin, a protein possessing specific highaffinity binding sites for the cell surface,

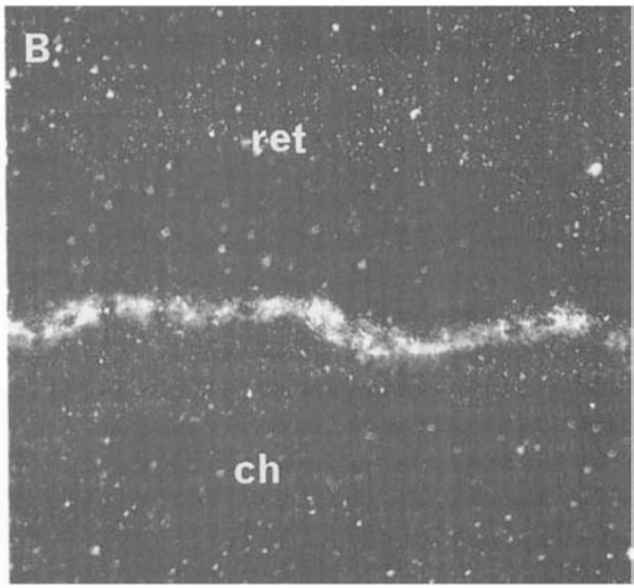

Fig. 5. (A) Immunofluorescence staining of cultured human RPE cells (obtained from Dr Boulton) using a commercially available monoclonal specific for cytokeratins $5 \& 8$ (RCK 102). (B) Immuno gold/silver staining of a cryostat section of human retina (ret) and choroid (ch) using the same monoclonal and detected using the immunogold method followed by silver enhancement. When viewed using epi-polarisation the metallic reaction product is clearly visible. This technique avoids the problems due to autofluorescence and pigmentation of the $R P E$ which tend to interfere with other techniques. The RPE is intensely positive. Both $x 250$. 
collagen, fibrin and sulphated proteoglycans has been localised to the basal aspect of the RPE cell in situ ${ }^{108,110-112}$ and in culture. ${ }^{109}$ One report ${ }^{113}$ has also localised fibronectin to the apical microvilli and the Golgi endoplasmic reticulum system of rat RPE. Integrin, a trans membrane protein involved in the linkage between fibronectin and actin has been localised to the basal aspect of chick and rat RPE ${ }^{111}$. Various proteoglycans have been localised to the Interphotoreceptor space ${ }^{114}$ and to the basal aspect of the RPE cell. ${ }^{108,109}$

Several authors have attempted to identify Fc and $\mathrm{C} 3 \mathrm{~b}$ receptors on the retinal pigment epithelium of dogs and rats. ${ }^{115,116}$ However, Eckhert and Hafeman in a recent study were unable to identify $\mathrm{Fc}$ or $\mathrm{C} 3 \mathrm{~b}$ receptors in the RPE cells of black eyed RCS rats or normal congenic $(\mathrm{rdy}+)$ rats. In the case of human RPE, HLA-DR antigens have been shown to be present on RPE cells obtained from retinitis pigmentosa patients but were absent from normal controls. ${ }^{117}$

A variety of other membrane proteins and receptors have been shown to be present in RPE cells. Sodium potassium ATPase, which comprises of two subunits of $95 \mathrm{kD}$ and $40 \mathrm{kD}$, has been detected by immunofluorescence. Preparations of Na,K-ATPase from the brain and the retina have two biochemically distinct isozymes of the catalytic $(95 \mathrm{kD})$ subunit called $\alpha$ and $\alpha(+)$. The $\alpha$ but not the $\alpha(+)$ isozyme appears to be present in the retinal pigment epithelium of the rat. ${ }^{118}$ Receptors for mannose-6-phosphate, ${ }^{119}$ transferrin ${ }^{120}$ and insulin-like growth factor 120 have been demonstrated to be present. Proteins associated with the transport of retinol/retinal, cellularretinol binding protein $(\mathrm{CRPB})^{121}$ and 11 -cis retinaldehyde binding (CRALBP) ${ }^{122}$ have been detected in the retinal pigment epithelium by immunocytochemical techniques.

Several abstracts outlining the production and preliminary characterisation of MAbs to specific RPE antigens have been published but to the best of our knowledge no detailed papers have appeared. ${ }^{123-126}$ Our own efforts in this direction have yielded two groups of MAbs: one showing considerable reactivity with other epithelia and the other showing striking specificity for the RPE in situ but failing to react with proliferating RPE in pathological material or cultured RPE cells (Fig. 6). Rather than finding useful markers

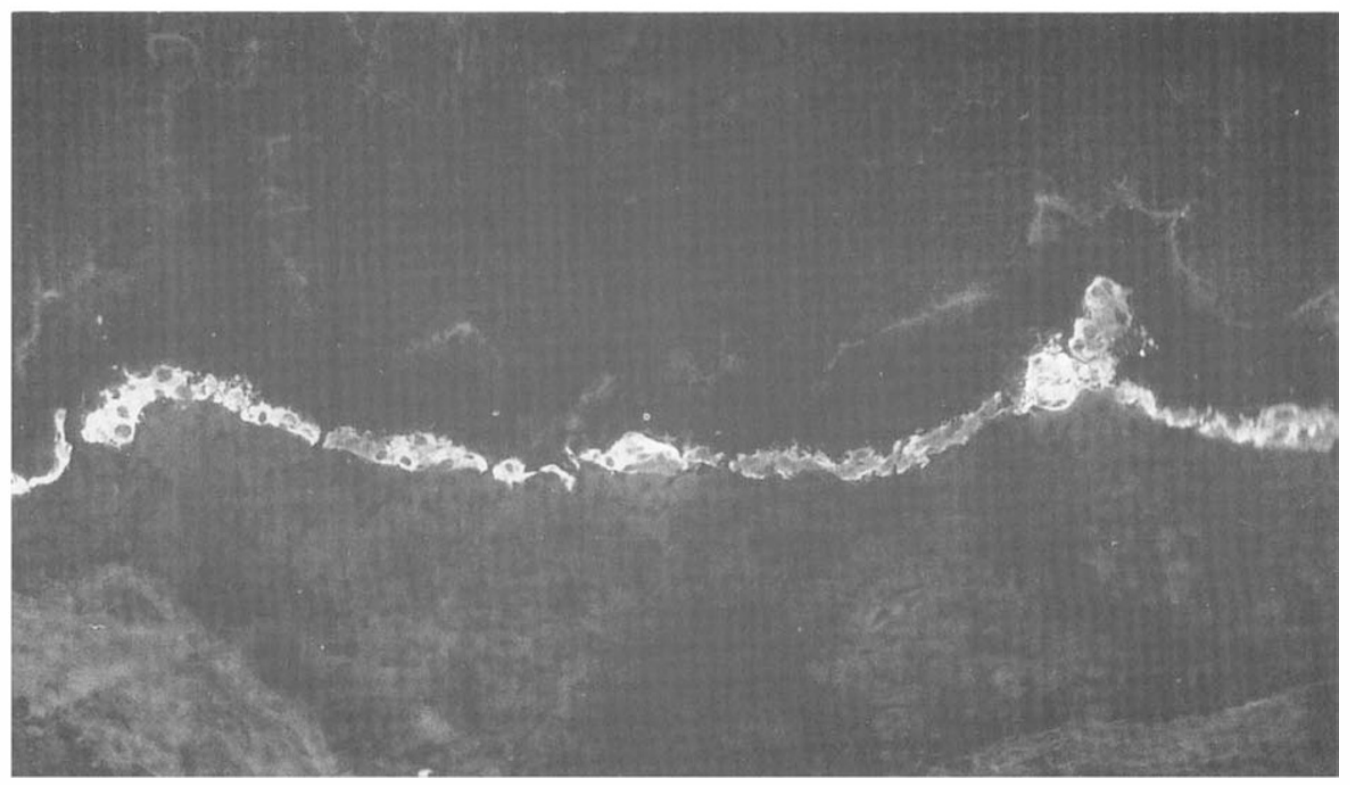

Fig. 6. Cryostat section of cat retina and choroid (tapetal region). The section has been immunostained with a monoclonal antibody (RPE 42D3) which was obtained from a fusion where the mouse had been immunised with whole bovine RPE cells. The RPE is intensely fluorescent. This antibody also recognises non-ocular simple and glandular epithelial cells (x 160). 
of RPE cells in culture and pathology as initially intended these antibodies may prove useful in the identification of proteins specific to functional RPE.

We would like to acknowledge the financial support of the Special Trustees of Moorfields Eye Hospital, the British Retinitis Pigmentosa Society and Fight for Sight.

\section{References}

${ }^{1}$ Molday RS, .Hicks D, Molday L. Peripherin. A rim-specific membrane protein of rod outer segment discs. Invest Ophthalmol Vis Sci 1987; 28: $50-61$.

${ }^{2}$ Towbin H, Staehelin T, Gordon J. Electrophoretic transfer of proteins from polyacryliamide gels to nitrocellulose sheets: procedures and some applications. Proc Natl Acad Sci USA 1979; 16: 4350-4.

${ }^{3}$ Gregerson DS, and Abrahams IW. Immunologic and biochemical properties of several retinal proteins bound by antibodies in sera from animals with experimental autoimmune uveitis and uveitis patients. J Immunol 1983; 131: 259-64.

${ }^{4}$ Bendayan M. Protein A - gold electron microscopic immunocrytochemistry: methods, applications and limitations. J Electron Microsc Tech 1984; 1: 243-70.

${ }^{5}$ Ramaekers F, Pats J, Moesker O, Kant A, Jap P, Vooijs P. Demonstration of keratin in human adenocarcinomas. Am J Path 1983; 111: 213-23.

${ }^{6}$ Pinkus GS, O'Conner EM, Etheridge CL. Corston JM. Optimal immunoreactivity of keratin proteins in formalin-fixed paraffin embedded tissues requires preliminary trypsinisation. $J$ Histochen Cytochem. 1985; 33: 465-73.

${ }^{7}$ Satox Y, Mukai K, Watanabe S, Goto M, Shimosato Y. The AMeX method. A simplified technique of tissue processing and paraffin embedding with improved preservation of antigens for immune staining. Am J Path 1986; 125: 431-5.

${ }^{8}$ Tolson ND, Boothroyd B, Hopkins CR. Cell surface labelling with colloid particulates: the use of avidin and staphylococcal protein A - coated gold in conjunction with biotin and $\mathrm{fc}-$ bearing legends. J Microscopy 1981; 123: 215-26.

${ }^{9}$ Roth J. The protein A - gold (pAg) technique. Qualitive and Quantitative approach for antigen localisation on thin sections. In Immunocytochemistry. Techniques and applications Eds Bullock GR and Petrusz 'P. Academic Press London. 1982: 108-33.

${ }^{10}$ Roof DJ, and Heuser JE. Surfaces of rod photoreceptor disk membranes: Integral membrane components. J Cell Biol - 1982; 95: 487-500.
"Cohen AI. New evidence supporting the linkage to the extracellular space of outer segment saccules of frog cones but not rods. J Cell Biol 1968; 37: 424-44.

${ }^{12}$ Hubell WL, Fung BK-K, Chen Y, Honk K. Molecular anatomy and light-dependent processes in photoreceptor membranes. In Vertebrate Photoreception Eds. Barlow HB and Fatt P. Acadamic Press NY 1977: 41-59.

${ }^{13}$ Dewey MM, Davis PK, Blasie, JK Barr L. Localisation of rhodopsin antibody in the retina of the frog. J Mol Biol 1969: 39: 395-405.

${ }^{14}$ Jan LY, and Revel JP. Ultrastructural localisation of rhodopsin in the vertebrate retina. J Cell Biol. 1974; 62: 257-73.

${ }^{15}$ Papermaster DS, Schneider BG, Zorn MA, Kraehenbuhl JP. Immunocytochemical localisation of opsin in the outer segments and Golgi zones of frog photoceptor cells. An electron microscope analysis of cross-linked albuminembedded retinas. J Cell Biol 1978; 77: 196-210.

${ }^{16}$ Barnstable CJ. Monoclonal antibodies which recognise different cell types in the rat retina. Nature 1980; 286: 231-5.

${ }^{17}$ Fekete DM, and Barnstable CJ. The subcellular localisation of rat photoceptor - specific antigens. J Neurocytol. 1983; 785-803.

${ }^{18}$ Hicks D, and Molday RS. Differential immunogold - dextran labelling of bovine and frog rod and cone cells using monoclonal antibodies against bovine rhodopsin. Exp Eye Res 1986; 42: 55-71.

${ }^{19}$ Wacker WB, Donoso LD, Kalsow CM, Yankeelov JA, Organisciak DT. Experimental allergic uveitis. Isolation, characterisation and localisation of a soluble uveitophathogenic antigen from bovine retina. J Immunol 1977; 119: 1949-58.

${ }^{20}$ Al-Mahdawi S, Forrester JV, Lee WR. A simplifed method for the isolation of highly purified bovine retinal S-antigen. $J$ Neuroimmunol 1987; 14: 99-108.

${ }^{21}$ Faure JP. Autoimmunity and the retina Curr Top Eye Res 1980; 2: 215-302.

${ }^{22}$ Gery I, Mochizuki M, Nussenblatt RB. Retinal specific antigens and immunopathogenic processes they provoke. Prog Ret Res 1986; 5: 75-109.

${ }^{23}$ Pfister C, Chabre M, Plouet J. Tuyen VV., de Kozak Y. Faure, JP, Kuhn H. Retinal s-antigen identified as the $48 \mathrm{k}$ protein regulating light dependent phosphodiestrase in in rods. Science 1985; 228: 891-3.

${ }^{24}$ Kalsow CM, and Wacker WB. Localisation of a uveitogenic soluble retinal antigen in the normal guinea pig eye by an indirect fluorescent antibody technique. Int Arch Allergy 1973; 44: 11-20. 
${ }^{25}$ Kalsow CM, and Wacker WB. Pineal gland involvement in retina-induced experimental allergic uveitis. Invest Ophthal Vis Sci 1978; 17: 774-83.

${ }^{26}$ Korf H, Moller M. Gery I. Zigler S, Klein DC. Immunocytochemical demonstration of retinal Santigen in the Pineal organ of four mammalian species. Cell tissue Res. 1985; 239: 81-5.

${ }^{27}$ Wacker WB. Retinal autoimmunity and the pathogenesis of uveitis. In: Proceeding "Immunology of the Eye, Workshop II, Eds R J Helmsen, A Suram, I Gery and R B Nussenblatt. 1981; 11-32.

${ }^{28}$ Yajima S, Seki F, Takano S, Usui M. Localisation of S-antigen by enzyme-labelled-antibody method and electron microscopy. Jpn $J$ Ophthalmol 1983; 27: 526-34.

${ }^{29}$ Yajima S, Hasemi M, Usui M. Localisation of Santigen under various conditions of light or dark adaptation in the rabbit. Jpn J Ophthalmol 1985; 29: 334-47.

${ }^{30}$ Broekhuyse RM, Leurissen JLM, Verkley AJ. Ultrastructural localisation of S-antigen in retinal structures. Curr Eye Res 1985; 4: 73-7.

${ }^{31}$ Uusitalo H, Lehtosalo JI, Gregerson DS, Uusitalo R, Palkama A. Ultrastructural localisation of retinal S-antigen in the rat. Graefe's Arch Clin Exp Ophthalmol 1985; 222: 118-22.

${ }^{32}$ McKechnie N, Al-Mahdawi S, Dutton G, Forrester JV. Ultrastructural localisation of retinal S-antigen in the human retina. Exp Eye Res 1986; 42: 479-87.

${ }^{33}$ Das ND, Ulshafer RJ, Zam ZS, Leverenz VR, Shichi H. Radioimmunocytochemical localisation of retinal S-antigen with monoclonal antibodies. J Histochem Cytochem 1984; 32: 834-8.

${ }^{34}$ Faure J-P, Mirshahi M, Dorey C, Thillaye B, de Kozak Y, Boucheix C. Production and specificity of monoclonal antibodies to retinal S-antigen. Curr Eye Res 1984; 3: 867-72.

${ }^{35}$ Donoso LA, Merryman CF, Edelberg KE, Naids $\mathrm{R}$, Kalsow C. S-antigen in the developing retina and pineal gland: a monoclonal antibody study. Invest Ophthal Vis Sci 1985; 26: 561-7.

${ }^{36}$ Mirchahi M, Boucheix C. Collenot G, Thillaye B, Faure JP. Retinal S-antigen epitopes in vertebrate and invertebrate photoreceptors. Invest Ophthal Vis Sci 1985; 26: 1016-21.

${ }^{37}$ Reid DM, Loeffler KU, Campbell AM, Forrester JV. Electron immunocytochemical focalisation of retinal S-antigen with a rat monoclonal antibody. Exp Eye Res 1987; 45: 731-45.

${ }^{38}$ Miki N, Baraban JM, Keirns JJ, Boyce JJ, Bitensky MW. Purification and properties of the light-activated cyclic nucleotide phosphodiesterase of rod outer segments J Biol Chem 1975; 250: 6320-7.
${ }^{39}$ Etingof RN, Kalinina SN, Dumler IL. Immunochemical study of the cyclic nucleotide system of retinal photoreceptor membranes. Antibodies raised to phosphodiesterase, its protein inhibitor and GTP - binding proteins. Vision Res. 1986; 26: 415-23.

${ }^{40}$ Hurwitz RL, Bunt-Milam AH, Beavo JA. Immunologic characterisation of the photoreceptor outer segment cyclic GMP phosphodiesterase. J Biol Chem 1984; 259: 8612-18.

${ }^{41}$ Hamm HE, and Bownds MD. A monoclonal antibody to guanine nucleotide binding protein inhibits the light-activated cyclic GMP pathway in frog rod outer segments. J Gen Physiol 1984. 84: 265-80.

${ }^{42}$ Farber DB, and Bok D. cGMP phosphodiesterase of retinal photoreceptor. Specific localisation in rods demonstrated by immunocytochemistry. J Cell Biol 1984; 99: 64a.

${ }^{43}$ Farber DB, and Shuster T. A Cyclic necleotides in retinal function and degeneration. In: The retina: A model for cell biology. Part 1 Eds. Adler R, and Farber D. Acadaemic Press 1986: 239-296.

${ }^{44}$ Kuhn H. Interactions between photoexcited rhodopsin and light-activated enzymes in rods. Prog. in Retinal Res. 1985; 5: 123-56.

${ }^{45} \mathrm{Kuhn} \mathbf{H}$. Interactions of rod cell proteins with the disk membrane: influence of light, ionic strength, and nucleotides. In Current Topics in Membranes and Transport Ed. Miller WH. 1981; 15: 171-201.

${ }^{46}$ Fung Bk, Hurley JB, Stryer L. Flow of information in the light-triggered cyclic nucleotide cascade of vision. Proc Natl Acad Sci USA 1981; 78: 152-6.

${ }^{47}$ Grunwald GB, Gierschik P. Nirenberg M, Spiegel A. Detection of $\alpha$-transducin in retinal rods but not cones. Science 1986; 231: 856-9.

${ }^{48}$ Witt PL, Hamm HE, Bownds MD. Preparation and characterization of monoclonal antibodies to several frog rod outer segment proteins. J. Gen. Physiol 1984; 84: 251-63.

${ }^{49}$ Papermaster DS, Converse CA, Zorn MA. Biosynthetic and immunochemical characterization of a large protein in frog and cattle rod outer segment membranes. Exp. Eye Res. 1976; 23: 105-16.

${ }^{50}$ Converse CA. The large intrinsic membrane protein in rod outer segments: In vitro synthesis in cattle, and comparison in humans and rabbits. Exp. Eye Res. 1979; 29: 409-16.

${ }^{51}$ Papermaster DS, Schneider BG, Zorn MA, Krachenbuhl JP. Immunocytochemical localization of a large intrinsic membrane protein to the incisures and margins of frog rod outer segment disks. J. Cell Biol. 1978; 78: 415-25. 
${ }^{52}$ Papermaster DS, Reilly P, Schneider BG. Cone lamellae and red and green rod outer segment disks contain a large intrinsic membrane protein on their margins: an ultrastructural immunocytochemical study of frog retinas. Vision Res. 1982; 22: $1417-28$.

${ }^{53}$ McKenzie D. and Molday RS. Organization of rhodopsin and a high molecular weight glycoprotein in rod photoreceptor disc membranes using monoclonal antibodies. J. Biol. Chem. 1982; 257: 7100-5.

${ }^{54}$ Kalsaw CM and Wacker WB. Rabbit ocular and pineal auto immune response to retina antigens. Curr Eye Res 1986; 5: 579-86.

${ }^{55}$ Pollard TD, Selden SC, Maupin P. Interaction of actin filaments with microtubules. J Cell Biol 1984; 99: 33s-37s.

${ }^{56}$ Murray RL, and Dubin MW. The occurrence of actin like filaments in association with migrating pigment granules in frog retinal pigment epithelium. J Cell Biol 1975; 64: 705-10.

${ }^{57}$ Chaitin MH, Schneider BG, Hall MO, Papermaster DS, Actin in the photoreceptor connecting cilium: ' Immunocytochemical localisation to the site of outer segment disk formation. J Cell Biol 1984; 99: 239-47.

${ }^{58}$ Chaitin $\mathrm{MH}$, and Bok D. Immunoferritin localisation of actin in retinal photoreceptors. Invest Ophthal Vis Sci 1986; 27: 1764-7.

${ }^{59}$ Roof D, and Applebury M. Localisation of calmodulin and characterisation of clamodulin binding proteins in the vetebrate rod outer segment. Biophys $J$ 1984; 45:

${ }^{60}$ Kaplan MW, Iwata RT, and Sears RC. Lengths of immunolabelled ciliary microtubules in frog photoreceptor outer segments. Exp Eye Res 1987; 44: 623-32.

${ }^{61}$ Wong S, and Molday RS. A spectrin-like protein in retinal rod outer segments. Biochem 1986; 25 : 6294-300.

${ }^{62}$ Szel A, Takacs L, Monostori E, Diamantsein T, Vigh-Teichmann I, Rohlich P. Monoclonal antibody - recognising cone visual pigment. Exp Eye Res 1986; 43: 871-83.

${ }^{63}$ Lemmon V. A monoclonal antibody that binds to cones. Invest Ophthal Vis Sci 1986; 27: 831-6.

${ }^{64}$ Johnson JV, and Hageman GS. Characterisation of molecules bound by the cone photoreceptor specific monoclonal antibody CSA-1. Invest Ophthal Vis Sci 1988; 29: 550-7.

${ }^{65}$ Nishizawa Y, Kurihara T, Takahashi Y. Immunohistochemical localisation of $2^{\prime} 3^{\prime}-$ cyclic nucleotide $3^{\prime}$ - phosphodiesterase in the retina. Brain Res 1982; 251: 384-7.

${ }^{66}$ Kohsaka S, Nishimura Y, Takamatus K, Shimai K, Tsukada Y. Immunohistochemical localisation of 2',3' - cylic nucleotide $3^{\prime}-$ phosphodiesterase and myelin basic protein in the chick retina. $J$ Neurochem 1983; 41: 434-9.

${ }^{67}$ Wiechmann AF, Bok D, Horwitz J. Localisation of Hydroxyindole - $\mathrm{O}$ - Methyl - transferase in the mammalian pineal gland and retina. Invest Ophthl Vis Sci 1985; 26: 253-65.

${ }^{68}$ Hatakenaka S, Kuo $\mathrm{CH}$, Miki N. Analysis of distinctive protein in chick retina during development. Dev Brain Res 1983; 10: 155-63.

${ }^{69}$ Hatakenaka S. Kiyama H, Tohyama M, Mike N. Immunohistorchemical localisation of chick retinal $24 \mathrm{~K}$ dalton protein (Visinin) in various vertebrate retinae. Brain Res 1985; 331: 209-15.

${ }^{70}$ Pasteel B, Miki N, Hatakenaka S, Pochet R. Immunohistochemical cross-reactivity and electrophoretic co-migration between calbindin D-27 KDa and visinin. Brain Res 1987; 412: 107-13.

${ }^{71}$ Lin C-T, Song G-X, and Wu J-Y. Ultrastructural demonstration of L-glutamate decarboxylase and cysteine sulfinic acid decarboxylase in rat retina by immunocytochemistry. Brain Res 1985; 331: 71-80.

${ }^{72}$ Adler AJ and Klucznik KM. Proteins and glycoproteins of the bovine interphotoreceptor matrix: composition and fractionation. Exp Eye Res 1982; 34: 423-34.

${ }^{73}$ Adler AJ and Martin JK. Retinol-binding proteins in bovine interphotoreceptor matrix. Biochem Biophys Res Commun 1982; 108: 1601-8,

${ }^{74}$ Adler AJ, and Severin KM. Proteins of the Bovine interphotoreceptor matrix: tissues of origin. Exp Eye Res 1981; 32: 755-69.

${ }^{75}$ Pfeffer B, Wiggert B, Lee L, Zonnenberg B, Newsome D, Chader G. The presence of a soluble interphotoreceptor retinol-binding protein (IRBP) in the retinal interphotoreceptor space. J Cell Physiol 1983; 117: 333-41.

${ }^{76}$ Bunt - Milam A and Saari J. Immunochemical localisation of two retinoid - binding proteins in vertebrate retina. J Cell Biol 1983; 97: 703-12.

${ }^{77}$ Wiggert B, Derr J, Fitzpatrick M, Chader G. Vitamin A receptors of the retina. Differential binding in light and dark. Biochem Biophys Acta 1979; 582: 115-21.

${ }^{78}$ Liou GI, Bridges CD, Fong SL, Alvarez RA. Gonzalez Fernades F. Vitamin A transport between retina and pigment epithelium - an interstitial protein carrying endogenous retinol (interstitial retinol - binding protein) Vision Res 1982; 22: 1457-67.

${ }^{79}$ Wiggert B, Lee L, O'Brien P, Chader G. Synthesis of interphotoreceptor retinoid - binding protein (IRBP) by monkey retina in organ culture: effect of monensin. Biochem Biophys Res Commun 1984; 118: 789-96. 
${ }^{80}$ Hollyfield JG, Fliesler SJ, Rayborn ME, Fong SL, Landers RA, Bridges CDB. Synthesis and secretion of interstitial retinol binding protein by the human retina. Invest Ophthal Vis Sci 1985; 25: 58-67.

${ }^{81}$ Veen $T$ van, Katial A, Shinohara T, Barrett DJ, Wiggert B, Chader GJ, Nickerson JM. Retinal photoreceptor neurons and pinealocytes accumulate mRNA for interphotoreceptor retinoid binding protein (IRBP) FEBS lett 1986; 208: 133-7.

${ }^{82}$ Fong SL, Liou GI, Landers RA, Alvarez RA, Gonzales-Fernandes F, Glazebrook PA, Lam DMK, Bridges CDB. The characterisation, localisation and biosynthesis of an interstitial retinol - binding glycoprotein in the human eye. J Neurochem 1984; 42: 1667-76.

${ }^{83}$ Bridges CDB, Landers RA, Fong SL, GonzalezFernandes F, Lam DMK, Liou GI. Visual cycle in the the mammalian eye: retinoid - binding proteins and the distribution of 11-cis retinoids. Vision Res 1984; 24: 1581-94.

${ }^{84}$ Eisenfeld AJ, Bunt-Milam AH, Saari JC. Immunocytochemical localisation of interphotoreceptor retinoid - binding protein in developing normal and RCS rats. Invest Ophthalmol Vis Sci 1984; 26: 775-8.

${ }^{85}$ Schneider BG, Papermaster DS, Liou GI, Fong SL, Bridges CD. Electron microscopic immunocytochemistry of interstitial retinol - binding protein in vertebrate retinas. Invest Ophthalmol Vis Sci 1986; 27: 679-88.

${ }^{86}$ Rodrigues MM, Hackett J, Gaskins R, Wiggert B, Lee L. Redmond M, Chader GJ. Interphotoreceptor retinoid - binding protein in retinal rod cells and pineal gland. Invest Ophthalmol Vis Sci 1986; 27: 844-50.

${ }^{87}$ Anderson DH, Neitz J, Saari JC, Kaska DD, Fenwick J, Jacobs GH, Fisher SK. Retinoid binding proteins in cone-dominant retinas. Invest Ophthal Vis Sci 1986; 27: 1015-26.

${ }^{88}$ Shuster TA, Walter AE, Williams DS, Farker DB. Identification of a peanut agglutinin - binding protein from human retina. Exp Eye Res 1987; 45: 685-94.

${ }^{89}$ Hageman GS, and Johnson LV. Chondroitin $6-$ Sulfate glycosaminoglycan is a major constituent of primate cone photoreceptor matrix sheaths. Curr. Eye Res 1987; 6: 639-46.

${ }^{90}$ Bunt-Milam AH, Saari JC, Bredberg DL. Characterisation of the interstitial space: Immunocytochemical and biochemical studies. In: The interphotoreceptor matrix in health and disease Eds: Bridges CD and Alder A. New York, Alan R. Liss inc, 1985; 151-170.

${ }^{91}$ Gordon SR, and Essrat E. Investigations on circumferential microfilament bundles in rat retinal pigment epithelium. Euro J Cell Biol 1987; 44: 97-109.

${ }^{92}$ Opas M, and Kalnins VI. Spatial distribution of cortical proteins in cells of epithelial sheets. Cell Tissue Res 1985; 239: 451-4.

${ }^{93}$ Turksen K, Opas M, Aubin JE, Kalnins VI. Microtubules microfilaments and adhesion patterns in differentiating chick retinal pigment epithelium (RPE) cells in vitro. Exp Cell Res 1983; 147: 379-91.

${ }^{94}$ Owaribe K. Sugino H, Masuda H. Characterisation of intermediate filaments and their structural organisation during epithelium formation in pigmented epithelial cells of the retina in vitro. Cell Tissue Res. 1986; 244: 87-93.

${ }^{95}$ Haley JE, Flood MI, Gouras P, Kjeldbye HM. Proteins from human retinal pigment epithelial cells: Evidence that a major protein is actin. Invest Ophthalmol Vis Sci 1983; 24: 803-11.

${ }^{96}$ Owaribe K, Kodama N, Eguchi G. Demonstration of contractility of circumferential actin bundles and its morphogenic significance in pigmented epithelium in vitro and in vivo. J Cell Biol 1981; 90: $507-14$.

${ }^{97}$ Chaitin MH, and Hall MO. The distribution of actin in cultured normal and dystrophic rat pigment epithelial cells during the phogocytosis of rod outer segments. Invest Ophthal Vis Sci 1983; 24: 821-31.

${ }^{98}$ Opas M, Turksen KL, Kalnins VI. Effects of iodoacetic acid on cytoskeleton and adhesiveness of the chick RPE cells in vitro. Invest Ophthalmol Vis Sci 1986; 27: 1068-74.

${ }^{99}$ Irons MJ, and Kalnins VI. Distribution of microtubules in cultured RPE cells from normal and dystrophic RCS rats. Invest Ophthalmol Vis Sci 1984; 25: 434-9.

${ }^{100}$ Hiscott PS, Grierson I, McLeod D. Retinal pigment epithelial cells in epiretinal membranes: and immunohistochemical study. Br J Ophthal 1984; 68: 708-14.

${ }^{101}$ Stramm LE, Haskins ME, McGovern MM, and Aguine GD. Tissue culture of cat retinal pigment epithelium. Exp Eye Res 1983; 36: 91-101.

${ }^{102}$ Docherty RJ, Edwards JG, Garrod DR. Chick embryonic pigmented retina is one of the group of epitheliod tissues that lack cytokeratins and have intermediate filaments composed of vimentin. J Cell Sci 1984; 71: 61-74.

${ }^{103}$ Opas M, Turksen K, Kalnins VI. Adhesiveness and distribution of vinculin and spectrin in retinal pigmented epithelial cells during growth and differentiation in vitro. Dev Biol 1985; 107: 269-80.

${ }^{104}$ Opas M, and Kalnins VI. Distribution of spectrin and lectin-binding materials in surface lamina of RPE cells. Invest Ophthalmol Vis Sci 1985; 26: 621-7. 
${ }^{105}$ Opas M. The focal adhesions of chick retinal pigmented epithelial cells. Can J. Biochem Cell Biol 1985; 63: 553-63.

${ }^{106}$ McKechnie NM, Boulton M, Robey HL, Savage JS, Grierson I. The cytoskeletal elements of human retinal pigment epithelium. In vitro and In vivo. J Cell Sci 1988. (In Press).

${ }^{107}$ Moll R, Franke WW, Schilier DL. The catalog of human cytokeratins: Patterns of expression in normal epithelia, tumours and cultured cells. Cell 1982; 31: 11-24.

${ }^{108}$ Turksen K, Aubin JE, Sodek J Kalnins VI. Localisation of laminin, type IV collagen, fibronectin, and heparan sulphate proteoglycan in chick retinal pigment epithelium basement membrane during embryonic development. $J$ Histochem Cytochem. 1985; 33: 665-71.

109 Turksen K, Aubin JE, Sodek J, Kalnins VI. Changes in the distribution of laminin, fibronectin, Type IV collagen, and heparan sulfate proteoglycans during colony formation by retinal pigmented epithelia cells in vitro. Coll Relat Res 1984; 4: 413-26.

${ }^{110}$ Kohno T, Sorgente N, Patterson R, Ryan SJ. Fibronectin and laminin distribution in the bovine eye. Jpn J Ophthalmol 1983; 27: 496-505.

${ }^{111}$ Philp NJ, and Nachmias VT. Polarised distribution of integrin and fibronectin in retinal pigment epithelium. Invest Ophthalmol Vis Sci 1987; 28: 1275-80.

${ }^{112}$ Ishibashi T, Kohno T, Sorgente N, Patterson R, Ryan SJ. Fibronectin of the chorioretinal interface in the monkey: Immunohistochemical and immunoelectron microscopic studies. Graefes Arch Clin Exp Ophthal 1985; 223: 158-63.

${ }^{113}$ Pino RM. Immunocytochemical localisation of fibronectin to the retinal pigment epithelium of the rat. Invest Ophthalmol Vis Sci 1986; 27: 840-4.

114 Porrello K, and La Vail MM. Immunocytochemical localisation of chondroitin sulfates in the interphotoreceptor matrix of normal and dystrophic rat retina. Curr Eye Res 1986; 5: 981-93.

115 Newsome DA, and Bowles C. Retinal pigmented epithelial cells exhibit immunoreceptors. Invest Ophthalmol Vis Sci 1979; (ARVO Supplement) 18: 51 .
${ }^{116}$ Eckhert CD, and Hafeman DB. Search for Fc and C3b receptors on black eyed RCS rat RPE cells. Curr Eye Res 1986; 5: 911-17.

${ }^{117}$ Detrich B, Rodrigues M, Chan CC, Tso MVM, Hooks JJ. Expression of HLA-DR antigens on retinal - pigment epithelium - cells in retinitis pigmentosa. Am J Ophthalmol 1986; 101: 584-90.

${ }^{118}$ McGrail KH, and Sweadner KJ. Immunofluorescent localisation of two different sodium potassium ATPase species in the rat retina and in identified dissociated retina cells. $J$ Neurosci 1986; 6: 1272-83.

119 Tarnowski BI, Shepherd V McLaughlin · BJ. Mannose-6-Phospate receptors on the plasma membrane on rat retinal pigment epithelial cells. Invest Ophthalmol Vis Sci 1988; 29: 291-7.

${ }^{120}$ Hunt RC, Davis AA, Devey A, Haskell J. Transferrin and insulin-like growth factor - 1 receptors on retinal pigment epithelia cells. Invest Ophthalmol Vis Sci 1987; (ARVO Supplement) 28: 255 .

${ }^{121}$ Bok D, Ong DE Chytil F. Immunocytochemical localisation of cellular retinol binding protein in the rat retina. Invest Ophthalmol Vis Sci 1984; 25: 877-83.

${ }^{122}$ Bunt-Milam A and Saari JC. Immunocytochemical localisation of the retinoid-binding proteins in vertebrate retina. J Cell Biol 1983; 97: 703-12.

${ }^{123}$ Kobayashi H, Ueda M, Yoshumura N, Ogino N, Hanaoka M. Retinal pigment epithelium tissue specific antigen detected by monoclonal antibody. Cell Struct Funct 1986; 10: Abstract 470.

${ }^{124}$ Dixon PA, Braunagel SC, Donoso LA, Organisciah DT. Retinal pigment epithelial plasma membrane proteins a monoclonal antibody study. Invest Ophthalmol Vis Sci 1986; 27: (ARVO Supplement) 10.'

${ }^{125}$ Hecks JJ, Siraganian R, Percopp C, Chan CC, Hamel C, Detrich B. Development and characterisation of monoclonal antibodies directed against the human retinal pigment epithelial cell. Invest Ophthalmol Vis Sci 1988; 29: (ARVO Supplement) 224.

${ }^{126}$ Neill JM, and Barnstable CJ. Two monoclonal antibodies label retinal pigment epithelial in vivo and in vitro. Invest Ophthalmol Vis Sci 1988; 29: (ARVO Supplement) 245. 